\begin{tabular}{|l|l|}
\hline $\begin{array}{l}\text { 2. To: (Receiving Organization) } \\
\text { Packaging Engineering }\end{array}$ & 3. From: (Originating Organization) \\
Packaging Engineering
\end{tabular}

8. Originator Remarks:

For approval and release.

11. Receiver Remarks: 11A. Design Baseline Document? [] Yes [X] No

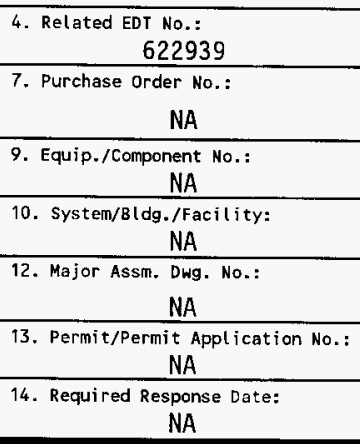

\begin{tabular}{|c|c|c|c|c|c|c|c|c|c|c|}
\hline \multicolumn{7}{|c|}{ 15. DATA TRANSMITTED } & \multirow{2}{*}{$\begin{array}{c}\text { (F) } \\
\text { Approval } \\
\text { Desig- } \\
\text { nator }\end{array}$} & \multirow[b]{2}{*}{$\begin{array}{c}\text { (G) } \\
\text { Reason } \\
\text { for } \\
\text { Trans- } \\
\text { mittal }\end{array}$} & \multirow[b]{2}{*}{$\begin{array}{c}\text { (H) } \\
\text { Origi- } \\
\text { nator } \\
\text { Dispo- } \\
\text { sition }\end{array}$} & \multirow[b]{2}{*}{$\begin{array}{c}\text { (I) } \\
\text { Receiv } \\
\text { er } \\
\text { Dispo- } \\
\text { sition }\end{array}$} \\
\hline $\begin{array}{l}\text { (A) } \\
\text { Item } \\
\text { No. }\end{array}$ & \multicolumn{2}{|c|}{ (B) Document/Drawing No. } & $\begin{array}{l}\text { (C) } \\
\text { Sheet } \\
\text { No. }\end{array}$ & $\begin{array}{l}\text { (D) } \\
\text { Rev. } \\
\text { No. }\end{array}$ & \multicolumn{2}{|c|}{$\begin{array}{l}\text { (E) Title or Description of Data } \\
\text { Transmitted }\end{array}$} & & & & \\
\hline 1 & \multicolumn{2}{|l|}{ HNF-3169 } & NA & 0 & \multicolumn{2}{|c|}{$\begin{array}{l}\text { LLCEDATA and LLCECALC } \\
\text { for Windows Version } \\
1.0 \text {, VoTume III: } \\
\text { Software Verification } \\
\text { and Validation }\end{array}$} & SQ & 1,2 & 1 & \\
\hline & & & & & & & & & & \\
\hline & & & & & & & & & & \\
\hline & & & & & & & & & & \\
\hline & & & & & & & & & & \\
\hline \multicolumn{11}{|c|}{16.} \\
\hline \multicolumn{2}{|c|}{ Approval Designator $(F)$} & \multicolumn{4}{|c|}{ Reason for Transmittal (G) } & \multicolumn{5}{|c|}{ Disposition (H) \& (II) } \\
\hline \multicolumn{2}{|c|}{$\begin{array}{l}\text { E, S, } Q, D \text { or N/A } \\
\text { (see WHC-CM-3-5, } \\
\text { Sec. 12.7) }\end{array}$} & $\begin{array}{l}\text { 1. Appro } \\
\text { 2. Relea } \\
\text { 3. Inform } \\
\end{array}$ & \multicolumn{2}{|c|}{$\begin{array}{l}\text { 4. Review } \\
\text { 5. Post-Review } \\
\text { 6. Dist. (Receipt A }\end{array}$} & ow. Required! & \multicolumn{2}{|c|}{$\begin{array}{l}\text { 1. Approved } \\
\text { 2. Approved w/commont } \\
\text { 3. Disapproved w/comment }\end{array}$} & \multicolumn{3}{|c|}{$\begin{array}{l}\text { 4. Reviewed no/comment } \\
\text { 5. Reviewed w/comment } \\
\text { 6. Receipt acknowledged }\end{array}$} \\
\hline
\end{tabular}

17. SIGNATURE/DISTRIBUTION

(See Approval Designator for required signatures)

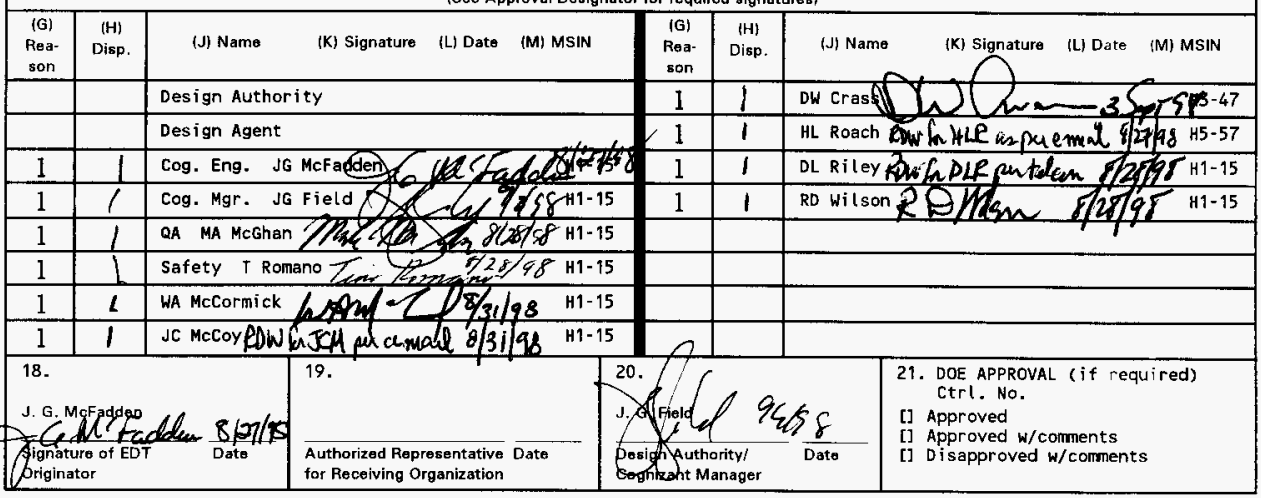

BD-7400-172-2 (05/96) GEF097 


\section{LLCEDATA and LLCECALC for Windows Version 1.0, Volume III: Software Verification and Validation}

\section{J. G. McFadden}

Waste Management Federal Services, Inc., Northwest Operations

Richland, Washington 99352

for Fluor Daniel Hanford, Inc.

U.S. Department of Energy Contract DE-AC06-96RL13200

EDT/ECN: EDT $622943^{2} \quad$ UC: $513,4 c: 2000$

Org Code: $03 \mathrm{E} 00$

Charge Code: 06309 Task Order: GS080003

Project: 772028 Crosswalk: 40-007-001

B\&R Code: EW3130010 Total Pages: 55

Key Words: LLCE, Long-Length Contaminated Equipment, residual waste, characterization, GEA System, FRRDS

Abstract: LLCEDATA and LLCECALC for Windows Version 1.0 are userfriendly computer software programs that work together to determine the proper waste designation, handling, and disposition requirements for Long-Length Contaminated Equipment. LLCEDATA and LLCECALC generate characterization information by integrating the acquisition of current tank waste data with the output from the Gamma Energy Analys is System, a component of the Flexible Receiver Radiation Detection System.

Documentation for LLCEDATA and LLCECALC for Windows is available in three volumes. Volume I is a user's manual, which is intended as a quick reference; Volume II is a technical manual; and Volume III is a software verification and validation document.

TRADEMARK DISCLAIMER. Reference herein to any specific comercial product, process, or service by trade name, trademark, manufacturer, or otherwise, does not necessarily constitute or imply its endorsement, recommendation, or favoring by the United States Government or any agency thereof or its contractors or subcontractors.

Printed in the United States of America. To obtain copies of this document, contact: WHC/BCS Document Control Services, P.0. Box 1970, Mailstop H6-08, Richland WA 99352, Phone (509) 372-2420; Fax (509) 376-4989.

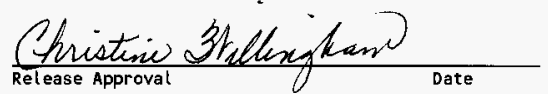

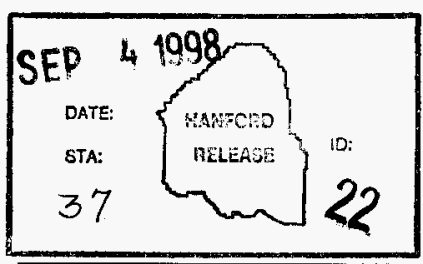

Release \$tamp 


\section{LLCEDATA AND LLCECALC FOR WINDOWS VERSION 1.0, VOLUME III: SOFTWARE VERIFICATION AND VALIDATION}

Cognizant Engineer: J. G. McFadden Prepared by: D. L. Riley, R. D. Wilson Software: H. L. Roach

August 1998

Prepared for the U.S. Department of Energy by Engineering Waste Management Federal Services, Inc., Northwest Operations 


\section{ACKNOWLEDGMENTS}

Version 1.0 of LLCEDATA and LLCECALC for Windows was supported by the U.S. Deparitinent of Energy. LLCEDATA and LLCECALC for Windows' authors would like to thank the following people for their support on this project: A. D. Kirby, L. D. Kandt, and J. C. McCoy. 
This page intentionally left blank. 


\title{
LLCEDATA AND LLCECALC FOR WINDOWS VERSION 1.0, VOLUME III: SOFTWARE VERIFICATION AND VALIDATION
}

\author{
Cognizant Engineer: J. G. McFadden \\ Prepared by: D. L. Riley, R. D. Wilson \\ Software: H. L. Roach
}

\begin{abstract}
LLCEDATA and LLCECALC for Windows' are user-friendly computer software programs that work together to determine the proper waste designation, handling, and disposition requirements for LongLength Contaminated Equipment (LLCE). LLCEDATA reads from a variety of databases to produce an equipment data file (EDF) that represents a "snapshot" of both the LLCE and the tank from which it originates. LLCECALC reads the EDF and the gamma assay file (AV2) that is produced by the Flexible Receiver Gamma Energy Analysis System. LLCECALC performs corrections to the AV2 file as it is being read and characterizes the LLCE. Both programs produce a variety of reports, including a characterization report and a status report. The status report documents each action taken by the user, LLCEDATA, and LLCECALC.
\end{abstract}

Documentation for LLCEDATA and LLCECALC for Windows is available in three volumes. Volume I is a user's manual, which is intended as a quick reference for both LLCEDATA and LLCECALC. Volume II is a technical manual, which discusses system limitations and provides recommendations to the LLCE process. Volume III documents LLCEDATA and LLCECALC's verification and validation. Two of the three installation test cases, from Volume I, are independently confirmed. Databases used in LLCEDATA are verified and referenced. Both phases of LLCECALC, process gamma and characterization, are extensively tested to verify that the methodology and algorithms used are correct.

'Windows is a trademark of Microsoft Corporation. 
LLCEDATA and LLCECALC for Windows are sponsored by the U.S. Department of Energy. They were developed and are maintained by Engineering, Waste Management Federal Services, Inc., _Northwest Operations. Copies of the software and documentation are available by contacting Engineering, Waste Management Federal Services, Inc., Northwest Operations, Richland, Washington. 


\section{FOREWORD}

This document presents the verification and validation basis for LLCEDATA and LLCECAEC for Windows. The databases used in LLCEDATA are verified and referenced. The methodology and algorithms used in LLCECALC are independently tested. Test cases used to debug the code during development are documented, and the confirmation of the bug eliminations is documented.

LLCEDATA and LLCECALC are software programs developed and maintained by Engineering, Waste Management Federal Services, Inc., Northwest Operations, Richland, Washington, for the U.S. Department of Energy. Documentation for the software programs exists in the form of LLCEDATA and LLCECALC for Windows Version 1.0, Volume I: User's Manual; LLCEDATA and LLCECALC for Windows Version 1.0, Volume II: Technical Manual; and LLCEDATA and LLCECALC for Windows Version 1.0, Volume II: Software Verification and Validation. The reader is urged to have all three documents available for reference when becoming familiar with the software prior to use. The software is available from Engineering by calling 509-376-0610 or 509-376-7111. Corrections and suggestions for additions or modifications to LLCEDATA and LLCECALC for Windows are welcome. 
This page intentionally left blank. 


\section{CONTENTS}

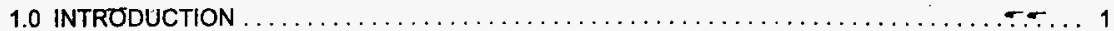

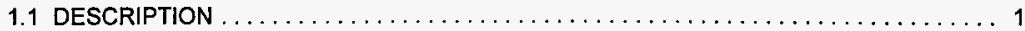

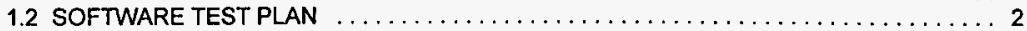

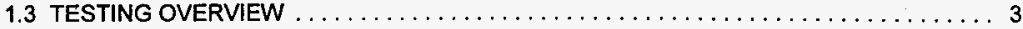

2.0 TEST CASES FOR INSTALLATION VERIFICATION $\ldots \ldots \ldots \ldots \ldots \ldots \ldots \ldots \ldots \ldots \ldots$

2.1 SYNTHETIC SINGLE-LAYER CASE: ONE-LAYER EDF WITH A COMPLEX AV2 FILE $\ldots 4$

2.2 SYNTHETIC MULTI-LAYER CASE: FIVE-LAYER EDF WITH SIMPLE AV2 FILE $\ldots \ldots \ldots$

2.3 VERIFICATION FILE DESCRIPTIONS FOR TWO VERIFICATION CASES $\ldots \ldots \ldots \ldots 8$

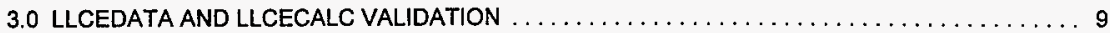

3.1 VALIDATION OF DATABASES USED IN LLCEDATA REQUIRED STEPS $\ldots \ldots \ldots \ldots \ldots 9$

3.1.1 LLCE Physical Database . . . . . . . . . . . . . . . . . . . . . . . 9

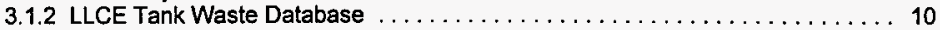

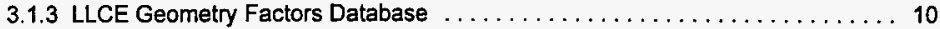

3.2 VALIDATION OF DATABASES USED IN LLCEDATA OPTIONAL STEPS $\ldots \ldots \ldots \ldots 11$

3.2.1 Validation of the Waste Container Data Database . . . . . . . . . . . . . . 11

3.2.2 Validation of the Radionuclide Constants Data Database . . . . . . . . . . . 11

3.2 .3 Validation the Radionuclide Limits Database . . . . . . . . . . . . . . . . . 12

3.2.4 Validation of the Chemical Limits Database .................. 13

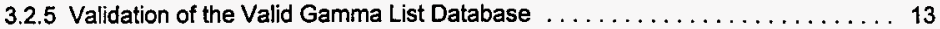

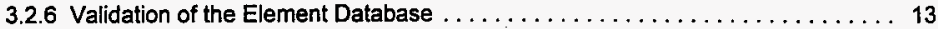

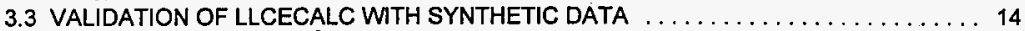

3.3.1 Discussion of ${ }^{137} \mathrm{Cs}$ Gamma Activity Validation Results . . . . . . . . . . . . 14

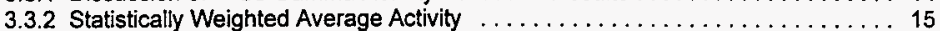

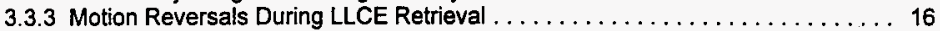

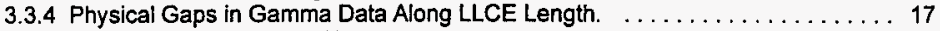

3.3.5 Multiple Layers of Tank Waste $\ldots \ldots \ldots \ldots \ldots \ldots \ldots \ldots \ldots \ldots \ldots \ldots$

3.4 DISCUSSION OF FILES USED TO VERIFY ${ }^{137}$ CS GAMMA ACTIVITY ALGORITHMS . . . 18

3.4.1 EDFs and Preparatory Gamma Assay Analysis Validation . . . . . . . . . 18

3.4.2 Fundamental Process Gamma AV2 File Reading Tests . . . . . . . . . . . . 19

3.4.3 Specific Tests to Confirm Removal of Intermediate Bugs . . . . . . . . . . 22

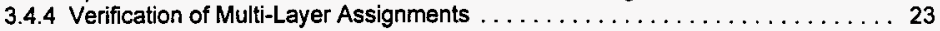

3.4.5 Verification for Shielding Correction Factors $\ldots \ldots \ldots \ldots \ldots \ldots \ldots \ldots \ldots$

4.0 LLCE WASTE CHARACTERIZATION VALIDATION $\ldots \ldots \ldots \ldots \ldots \ldots \ldots \ldots \ldots \ldots \ldots \ldots$

4.1 LLCECALC CHARACTERIZATION VERIFICATION, STEPS $1-3 \ldots \ldots \ldots \ldots \ldots \ldots \ldots$

4.2 LLCECALC CHARACTERIZATION VERIFICATION, STEP $4 \ldots \ldots \ldots \ldots \ldots \ldots \ldots \ldots \ldots$

4.3 LLCECALC CHARACTERIZATION VERIFICATION, STEPS $5-11 \ldots \ldots \ldots \ldots \ldots \ldots .29$

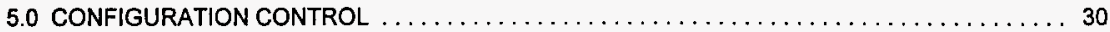

5.1 ARCHIVAL STORAGE AND RECORDS $\ldots \ldots \ldots \ldots \ldots \ldots \ldots \ldots \ldots \ldots \ldots \ldots \ldots \ldots$

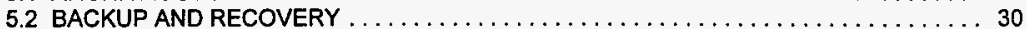

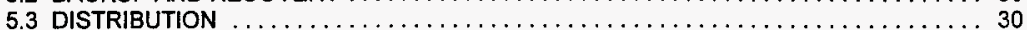

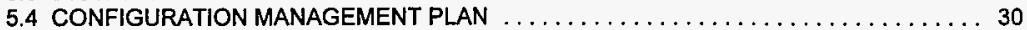

5.5 REQUIREMENTS SPECIFICATIONS $\ldots \ldots \ldots \ldots \ldots \ldots \ldots \ldots \ldots \ldots \ldots \ldots \ldots \ldots \ldots \ldots \ldots$

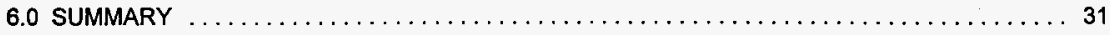

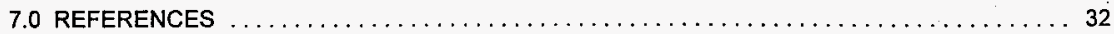




\section{CONTENTS (cont.)}

\section{APPENDIC̈ES}

A LLCEDATA AND LLCECALC CHANGE REPORT AND PROBLEM REPORT FORM . . . . . . . . A-i B VERIFICATION SPREADSHEETS FOR THE THREE CASES $\ldots \ldots \ldots \ldots \ldots \ldots \ldots \ldots \ldots$ B-i

\section{FIGURE}

2-1 LLCE and Multi-Layer Tank Configuration for Verification Case No. 2

\section{LIST OF TABLES}

2-1 Comparison of LLCECALC and Spreadsheet Characterization, Verification Case No. 1 . . . . . . 5

2-2 Comparison of LLCECALC and Spreadsheet Characterization, Verification Case No. $2 \ldots \ldots \ldots 7$

2-3 EDF, AV2, and XLS Files for Independent Validation of Verification Test Case No. 1 and No. 2 . . 8

3-1 Examples of Initial Gamma Analysis Validation $\ldots \ldots \ldots \ldots \ldots \ldots \ldots \ldots \ldots \ldots \ldots \ldots$

3-2 Comparisons of ${ }^{137} \mathrm{Cs}$ LLCECALC to Hand Calculations $\ldots \ldots \ldots \ldots \ldots \ldots \ldots \ldots \ldots$

3-3 Test Cases for Statistically Weighted Average Activity Validation $\ldots \ldots \ldots \ldots \ldots \ldots \ldots \ldots$

3-4 Comparison of LLCECALC and Spreadsheet ${ }^{137} \mathrm{Cs}$ Calculation, Verification Case No. $2 \ldots \ldots$

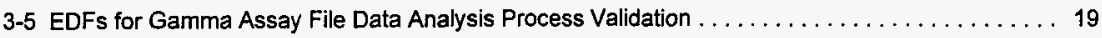

3-6 AV2 Files for Gamma Assay File Data Analysis Process Validation $\ldots \ldots \ldots \ldots \ldots \ldots \ldots \ldots$

3-7 Small Gap AV2 Files for Gamma Assay File Data Analysis Process Validation . . . . . . . . 22

3-8 EDF and AV2 Files for Multi-Layer Validation $\ldots \ldots \ldots \ldots \ldots \ldots \ldots \ldots \ldots \ldots \ldots \ldots \ldots$

3-9 EDF and AV2 Files for Validating Shielding Correction Factors $\ldots \ldots \ldots \ldots \ldots \ldots \ldots \ldots \ldots$

4-1 EDF, AV2, and XLS Files for Steps $1-3$ Characterization Validation $\ldots \ldots \ldots \ldots \ldots \ldots \ldots$

4-2 EDF, AV2, and XLS Files for Step 4, Transuranic Validation $\ldots \ldots \ldots \ldots \ldots \ldots \ldots \ldots \ldots$

4-3 EDF, AV2, and XLS Files for Steps $5-11$, Characterization Validation $\ldots \ldots \ldots \ldots \ldots \ldots \ldots 29$ 


\section{LIST OF TERMS}

\begin{tabular}{|c|c|}
\hline $\begin{array}{l}\text { AV2 } \\
\text { CAS } \\
\text { CD } \\
\text { DE-Ci } \\
\text { EDF } \\
\text { FGE } \\
\text { GEA } \\
\text { HRCQ } \\
\text { ISB } \\
\text { LLCE } \\
\text { NRC } \\
\text { PE-Ci } \\
\text { QA } \\
\text { SARP } \\
\text { TRU } \\
\text { TWINS } \\
\text { WMNW }\end{array}$ & $\begin{array}{l}\text { gamma assay (file) } \\
\text { Chemical Abstracts Service } \\
\text { compact disk } \\
\text { dose equivalent curie } \\
\text { equipment data file } \\
\text { fissile gram equivalent } \\
\text { Gamma Energy Analysis (System) } \\
\text { highway route controlled quantity } \\
\text { interim safety basis } \\
\text { Long-Length Contaminated Equipment } \\
\text { U.S. Nuclear Regulatory Commission } \\
\text { plutonium equivalent curie } \\
\text { quality assurance } \\
\text { safety analysis report for packaging } \\
\text { transuranic } \\
\text { Tank Waste Information Network System (database) } \\
\text { Waste Management Federal Services, Inc., Northwest Operations }\end{array}$ \\
\hline
\end{tabular}


This page intentionally left blank. 


\section{LLCEDATA AND LLCECALC FOR WINDOWS VERSION 1.0, VOLUME III: SOFTWARE VERIFICATION AND VALIDATION}

\subsection{INTRODUCTION}

\subsection{DESCRIPTION}

The Long-Length Contaminated Equipment (LLCE) disposal effort involves retrieval, handling, and disposal of the LLCE from any one of the 177 underground waste storage tanks, catch tanks, and lift stations. When the LLCE is retrieved from the tanks, every effort is made to remove any residual tank waste that is on the equipment surfaces. It is expected that some amount of tank waste will remain on the LLCE after retrieval. The radionuclide and chemical content of this residue must be assessed to determine the proper waste designation, handling, and disposition requirements for the LLCE.

It is the purpose of LLCEDATA and LLCECALC for Windows' Version 1.0 to generate characterization information by integrating the acquisition of current tank waste data with the output from the Gamma Energy Analysis (GEA) System, a component of the Flexible Receiver Radiation Detection System. LLCEDATA and LLCECALC provide an efficient, consistent, standardized, and documented methodology for performing characterization of an LLCE.

In order for the LLCECALC program to perform an LLCE characterization, LLCEDATA must first be used to create an equipment data file (EDF). The LLCEDATA program reads from a variety of databases, discussed in Section 2.3, to assemble the EDF. The LLCEDATA-produced EDF is a "snapshot" of the LLCE and its originating tank. The completed EDF, ready to be used by LLCECALC, contains complete information concerning the LLCE.

In addition to the LLCEDATA-generated EDF, the LLCECALC program requires a gamma assay file, known as the AV2 file. The gamma assay file is produced by the gamma isotope measurements from the GEA System. Once the EDF and AV2 file have been defined in LLCECALC, the LLCE characterization is ready to begin.

LLCEDATA and LLCECALC are Microsoft ${ }^{2}$ Windows Visual Basic ${ }^{3}$ executable programs that are menu driven and are easy for the user to navigate.

Three volumes document LLCEDATA and LLCECALC for Windows. Volume $l$ is a user's manual, which is intended for quick reference. It is to be used as an aid for learning to use LLCEDATA and LLCECALC for Windows and as a guide to the program's uses. The user's manual contains a discussion of all the options available to the user for each menu found in both LLCEDATA and LLCECALC. Volume II is a technical manual, which contains in-depth information on both programs. It gives information on the history of LLCEDATA and LLCECALC for Windows as well as the theoretical background and calculational methodology.

This document, Volume III, is the LLCE software verification and validation manual. The LLCE software is verified and validated utilizing several methods. First, the installation test cases discussed in . Volume I: User's Manual, Section 8.0, are verified. For these installation test cases, independent calculations are performed to confirm that both the ${ }^{137} \mathrm{Cs}$ calculations and the characterization are in agreement with the results from LLCECALC. Secondly, the process gamma and characterization

\footnotetext{
${ }^{1}$ Windows is a trademark of Microsoft Corporation.

${ }^{2}$ Microsoft is a trademark of Microsoft Corporation.

${ }^{3}$ Visual Basic is a trademark of Microsoft Comoration.
} 
methodology discussed in Volume II: Technical Manual, Section 2.0, are verified by independent spreadsheets that confirm that the results obtained from LLCECALC are identical to the results obtained from independent calculations. Finaliy, the software algorithms discussed in Volume II: Technical aManual, Section 2.0, are verified by independent spreadsheets. Specific synthetic EDFs and AV2 files were created to test the specific algorithms in LLCECALC. Confirmation of the algorithms was achieved by comparing the results from these synthetic test files to the results from the independent spreadsheets. These detailed validation discussions for both software programs demonstrate independent confirmation of the algorithms used by LLCECALC.

\subsection{SOFTWARE TEST PLAN}

The software programs LLCEDATA and LLCECALC provide for LLCE retrieval and "real timen gamma assay analysis and contamination characterization. These programs have become quite complex. This complexity has evolved because of severe demands placed on them by limitations in the gamma measurement process and by the difficulty in performing a well-controlled gamma measurement during the LLCE retrieval. It is important to test these complexities carefully to ensure that, for all foreseen conditions, the computed gamma activities for the LLCE are consistent with the established methodology and that they agree with hand calculations. To facilitate such comparisons, synthetic data files are created for various simplified cases. The cases are designed to test specific calculational features by holding all but the parameters of interest constant. In this way, all algorithms in the codes are tested individually and in concert to ensure proper operation of both the database software program, LLCEDATA, and the gamma assay analysis and characterization program, LLCECALC.

Initial tests with synthetic data uncovered bugs in both programs. Most bugs were not serious, but a few did affect the final results of the gamma assay analysis. The programs were corrected and tests repeated until the program results agreed with hand calculations for synthetic data. This debugging process was documented with a set of bug lists produced as the codes were modified, corrected, and retested. The bug lists and subsequent resolution action are documented in the project files as maintained by the code custodian.

The bug lists were maintained by tracking each bug with a unique bug number, type and classification of the bug, whether it was repeatable or not, and the version of the code where the bug was first seen. A comment was provided with each bug documenting the context and suggesting a resolution methodology. The bug list also contained a category for keeping track of and confirming the elimination of the bug. Each bug was identified by testing LLCEDATA and LLCECALC on a Windows 95 or Windows $N T^{4}$ computer. A few bugs were unique to one operating system or the other. The bug lists were generated by the author of these reports and submitted to the software author for resolution. The software author would then either fix the bug or suggest that the bug was not a bug by commenting on the original bug list. Confirmation of the elimination of each bug in the bug list was achieved by receiving both a candidate-resolved bug list and new version of LLCEDATA or LLCECALC from the program author. The new programs were then independently tested to confirm whether or not each bug should be marked as resolved. Some bugs, related to specific windows or interface-related problems, were confirmed as resolved on both operating systems discussed above. This dual operating system testing allowed debugging in a wider context. All bugs were confirmed to be resolved, and the output from LLCEDATA and LLCECALC was then used to create the verification reports in Volume I: User's Manual, Appendix A.

When the validated software is installed on a computer system for the first time, it is important to verify proper operation. This is accomplished with a set of verification test cases designed to test the important features of LLCEDATA and LLCECALC. The user must perform these verification test runs prior to use of the software in characterizing the contamination of an LLCE. Detailed instruction for performing this verification is provided in Volume I: User's Manual, Section 8.0. Results of these test cases as run on the new computer should agree exactly with results given in the software distribution as documented in Volume I: User's Manual, Section 8.0.

\footnotetext{
${ }^{4}$ Windows NT is a trademark of Microsoft Corporation.
} 


\subsection{TESTING OVERVIEW}

Between both the LLCEDATA and LLCECALC programs, five basic program characteristics were identified to be tested.

1. Reports. Both LLCEDATA and LLCECALC generate reports. Each report needed to be confirmed that it was reporting accurate information.

2. Operation. The general program operation of either LLCEDATA or LLCECALC is through menus and mouse selections. General testing was needed to confirm the menu structure, the program sequencing, option selection, and general options; e.g., units.

3. Databases. LLCEDATA utilizes several databases. The data in each database needed to be confirmed.

4. Process Gamma. The first process that LLCECALC performs is the process gamma activity. These nine steps terminate with an estimate of the total ${ }^{137} \mathrm{Cs}$ activity on the LLCE. This activity is used as the starting point for the second phase of LLCECALC, the characterization. Each of the nine steps and the ${ }^{137} \mathrm{Cs}$ activity calculations needed to be confirmed.

5. Characterization. The second process that LLCECALC performs is the characterization of the LLCE. This requires, as a starting point, the determination of the ${ }^{137} \mathrm{Cs}$ activity from the process gamma phase. Given a ${ }^{137} \mathrm{Cs}$ activity, 11 steps needed to be confirmed for this process.

The work presented in this document is meant to comply with the requirements of HNF-MP-599, Project Hanford Quality Assurance Program Description, as implemented in EBU-QAPP-001, Quality Assurance Program Plan for Project Hanford Management Contract Work (WMNW 1997). Sections 3.0 and 4.0 of this document outline in detail the techniques used to validate these five program characteristics. The validations presented in these two sections follow the requirement specification of acceptable levels of performance as discussed in Section 5.5 It is not within the scope of this software validation to determine or estimate the accuracy of the AV2 file generation process. All validations in this document assume, as a starting point, the given data in an AV2 file.

\subsection{TEST CASES FOR INSTALLATION VERIFICATION}

When the programs LLCEDATA and LLCECALC are installed on a computer for the first time, it is necessary for the user to verify that all features of both programs function correctly. This is accomplished by use of verification test cases. There are three installation verification test cases documented in the companion document, Volume I: User's Manual, Section 8.0 and Appendix A. The user's manual describes each verification case and includes copies of the reports generated by LLCEDATA and LLCECALC. Copies of the EDF and AV2 file are included with the code distribution so that verification cases can be run on the user's computer.

Each one of these three verification test cases was specifically chosen to check different features of the LLCEDATA and LLCECALC program. The three verification cases are summarized as follows:

1. A synthetic one-layer EDF with an AV2 file containing gaps, zero data, and backwards motion. This test case contains the simplest LLCE with a relatively complex AV2 file.

2. A synthetic five-layer EDF with an AV2 file of the simplest form. This test case confirms the multi-layer algorithm, with additional complexities of midlayer start points and midlayer 
geometry correction factors. To facilitate the understanding of a multi-layer tank, this test case contains the simplest AV2 file with no gaps, zero data, or backwards motion.

3.- A real LLCE case, based on historical data, and a real AV2 file. In this test case, the user creates the EDF by selecting an LLCE and tank that were manually analyzed in 1996.

The AV2 file used for this test case was generated by the GEA System and has not been modified.

The first two of these three verification test cases is independently confirmed to correctly characterize the LLCE. The second of these three test cases is independently confirmed to calculate the ${ }^{137} \mathrm{Cs}$ activity correctly. The following two sections outline the methodology used to construct these two cases and how they are confirmed.

\subsection{SYNTHETIC SINGLE-LAYER CASE: ONE-LAYER EDF WITH A COMPLEX AV2 FILE}

The first test case uses a synthetic gamma assay AV2 file, with a synthetic LLCE that is created specifically to test the ability of LLCECALC to work correctly with AV2 files that contain backward motion, gaps in the gamma records, and zero entries. The EDF for this test case has tank constituents that cause the LLCECALC characterization to be at the upper limit for most of the characterization decisions that are made. The LLCE is designed to be transuranic (TRU) and Type B.

Volume 1: User's Guide, Section 8.1, illustrates how LLCEDATA opens, in edit-mode, the c1_1layer.edf file for the purpose of generating two LLCEDATA reports. The synthetic c1_1layer.av2 file is specifically constructed to confirm the advanced algorithms used by LLCECALC to correct the anomalies that are sometimes present in AV2 files.

The specific characteristics for this first synthetic test case are specified as follows.

One tank layer: The layer thickness is specified to be $20 \mathrm{ft}$.

Content: The single layer has three chemicals and six radionuclides, including ${ }^{137} \mathrm{Cs}$.

LLCE: The LLCE is chosen to be positioned $5 \mathrm{ft}$ from the bottom of layer one. This is the "Tip-to-Bottom" dimension; however, for single layer tanks this dimension is not needed. The LLCE flange-to-tip length is $20 \mathrm{ft}$, and the entire LLCE is 25 ft long.

Geometry factors: There is only one set of geometry factors for this LLCE. The applicable range for this single set of factors is from $0 \mathrm{ft}$ to $20 \mathrm{ft}$.

For this verification case, Volume I: User's Manual, Section 8.1 and Appendix A, have the user compare the two reports from LLCEDATA and the characterization report from LLCECALC. Due to the relatively simple nature of this synthetic test case, it is possible to perform a complete independent validation. The results of processing this test case's EDF and AV2 file in LLCECALC are directly compared to independent calculations performed in an Excel spreadsheet. The Excel spreadsheet independently performs the same function as the characterization process of LLCECALC. Appendix B, Section B1.0, contains a copy of the spreadsheet used for this validation.

The spreadsheet in Appendix B, Section B1.0, appears as three "rows" or grouped blocks of data. The spreadsheet, when viewed in Excel, is only two "rows" of data, but too long to be formatted for the appendix. The second "row" of data should appear juxtaposed on the right of the first "row." The extra real row of data, on the bottom of the second "row," will then align with the first "row's" bottom row of data with the title "Sums" to the left. The characterization information is summarized in the bottom "row" of data with the title "The Important Numbers List." This is the summary that, when compared to the characterization report, confirms each characterization. This independent confirmation helps establish the accuracy of the algorithms used in the characterization portion of LLCECALC. 
Table 2-1 shows the comparison between LLCEDATA and the Excel spreadsheet. The column titled "LLCECALC" is the characterization data from the LLCECALC-produced characterization report, seen in Volume I: User's Manual, Appendix A, Section A1.2. The column titled "Spreadsheet" is the independently calculated characterization information from the Excel spreadsheet, seen in Appendix $B$, Section B1.0. The "\% Error" column is the error between the spreadsheet and LLCECALC; errors below one-thousandth of a percent are set to zero. The largest error, almost $0.2 \%$, arises due to LLCECALC reporting the "LLCE Pu Gram Content" with only three digits. This comparison confirms the accuracy of the algorithms used by the characterization portion of LLCECALC. This validation case assumes the ${ }^{137} \mathrm{Cs}$ activity is correct, obtained from the process gamma portion of LLCECALC. Section 2.2 contains an example that confirms that the process gamma portion of LLCECALC correctly calculated the ${ }^{137} \mathrm{Cs}$ activity.

Table 2-1. Comparison of LLCECALC and Spreadsheet Characterization, Verification Case No. 1.

\begin{tabular}{|l|c|c|c|}
\hline \multicolumn{1}{|c|}{ Compared Feature } & LLCECALC & Spreadsheet & $\%$ Error \\
\hline Category 1 Sum of Fractions & 242.60287 & $2.4260275 \mathrm{E}+02$ & 0 \\
\hline Category 3 Sum of Fractions & 1.15919 & $1.1591858 \mathrm{E}+00$ & 0 \\
\hline NRC Class C Sum of Fractions & 2.68052 & $2.6805190 \mathrm{E}+00$ & 0 \\
\hline ISB Category 3 Sum of Fractions & 0.03126 & $3.1255822 \mathrm{E}-02$ & 0.013 \\
\hline TRU Waste Sum of Concentrations & 1.22372 & $1.2237144 \mathrm{E}+00$ & 0 \\
\hline PE-Ci Curie Content Sum & 0.25494 & $2.5494050 \mathrm{E}-01$ & 0 \\
\hline PE-Ci Gram Weight Sum & 0.00248 & $2.4751505 \mathrm{E}-03$ & 0.196 \\
\hline PE-Ci Total Corrected Sum & 0.12871 & $1.2870783 \mathrm{E}-01$ & 0.002 \\
\hline Pu-239 Fissile Gram Equivalent Sum & 0.00557 & $5.5690886 \mathrm{E}-03$ & 0.016 \\
\hline Alpha Curie Content Sum & 0.26106 & $2.6105907 \mathrm{E}-01$ & 0 \\
\hline Heat Generation Rate for Waste Package & 53.13570 & $5.3135677 \mathrm{E}+01$ & 0 \\
\hline Transportation Category Sum & 1.88671 & $1.8867066 \mathrm{E}+00$ & 0 \\
\hline DE-Ci Tota: Sorrected Sum & 1.02231 & $1.0223114 \mathrm{E}+00$ & 0 \\
\hline
\end{tabular}

DE. $\mathrm{C}_{\mathrm{l}}=$ Dose equivalent curie.

ISB = Interim safety basis.

$\mathrm{PE}-\mathrm{Ci}=$ Plutonium equivalent curie.

NRC $=$ U.S. Nuclear Regulatory Commission TRU = Transuranic.

\subsection{SYNTHETIC MUL.TI-LAYER CASE: FIVE-LAYER EDF WITH SIMPLE AV2 FILE}

The second test case uses a synthetic gamma assay AV2 file, with a synthetic LLCE that is created specifically to test the multi-layer functionality of LLCEDATA and LLCECALC.

Volume I: User's Guide, Section 8.1, illustrates how LLCEDATA opens, in edit-mode, the $c 2$. 5 , , 3r.edf file, to generate the LLCEDATA reports. The synthetic c2_5layer.av2 file is constructed as simply as possible for this test-case to facilitate the ease of comparing just the data needed to confirm multi-layer functionality. 
The configuration of the synthetic five-layer tank is shown in Figure 2-1. Note that this figure is not drawn to scale. As outlined in the list below, the layer thickness decreases by a factor of two for each layer.

\section{Figure 2-1. L.LCE and Multi-Layer Tank Configuration} for Verification Case No. 2.

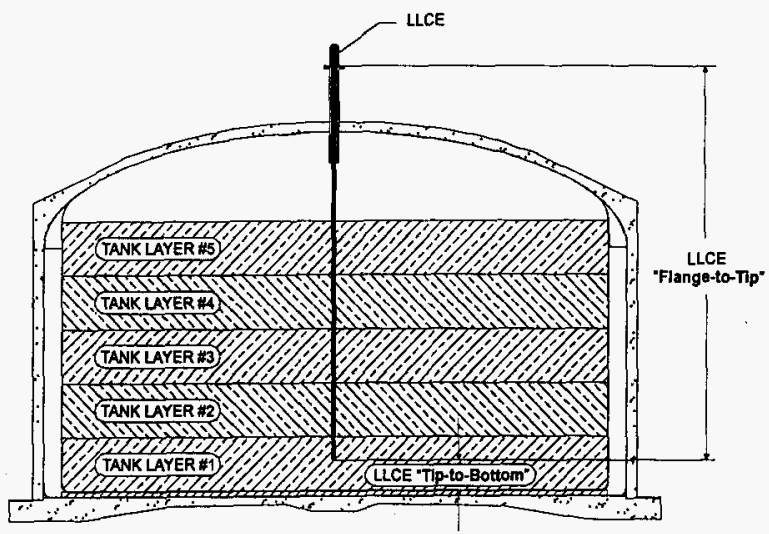

The specific characteristics for this second synthetic test case are specified as follows.

Five layers: The layer thicknesses, starting with layer one, are $10 \mathrm{ft}, 5 \mathrm{ft}, 2.5 \mathrm{ft}, 1 \mathrm{ft}$, and $0.5 \mathrm{ft}$ thick. The layer thicknesses shown in Figure 2-1 are not drawn to scale.

Content: Each of the five layers has one chemical and one radionuclide, in addition to the required ${ }^{137} \mathrm{Cs}$. Other than for ${ }^{137} \mathrm{Cs}$, the content is unique for each layer.

LLCE: The LLCE is chosen to be positioned $5 \mathrm{ft}$ from the bottom of layer one; this is the "Tip-to-Bottom" dimension. The "Flange-to-Tip" dimension is specified as $19 \mathrm{ft}$.

Geometry factors: There are three geometry factors for this LLCE. The applicable range for each set of factors is from 0 to $7.5 \mathrm{ft}, 7.5$ to $12.75 \mathrm{ft}$, and 12.75 to $19 \mathrm{ft}$ from the tip of the LLCE. Each of these three ranges end in the middle of one of the tank layers.

For this verification case, Volume I: User's Manual, Section 8.1 and Appendix A, has the user compare the two reports from LLCEDATA and the characterization report from LLCECALC to results from the software as installed on the user's computer. Due to the relatively simple nature of this synthetic test case, it is possible to perform a complete independent validation. The results of processing this test case's EDF and AV2 file in LLCECALC are directly compared to independent calculations performed in an Excel spreadsheet. The Excel spreadsheet independently performs the same function as the characterization process of LLCECALC. Appendix B, Section B2.0, contains a copy of the spreadsheet used for this validation.

The spreadsheet in Appendix B, Section B2.0, appears as three "rows," or grouped blocks of data. The spreadsheet, when viewed in Excel, is only two "rows" of data, but is too long to be formatted 
for the appendix. The second "row" of data should appear juxtaposed on the right of the first "row." The extra real row of data, on the bottom of the second "row," will then align with the first "row's" bottom row of data with the title "Sums" to the left. The characterization information is summarized in the bottom "row" of data with the title "The Important Numbers List." This is the summary that, when compared to the characterization report, confirms each characterization. This independent confirmation establishes the accuracy of the algorithms used in LLCECALC.

Table 2-2 shows the comparison between LLCEDATA and the Excel spreadsheet. The column titled "LLCECALC" is the characterization data from the LLCECALC-produced characterization report, seen in Volume I: User's Manual, Appendix A, Section A2.2. The column titled "Spreadsheet" is the independently calculated characterization information from the Excel spreadsheet, seen in Appendix $B$, Section B2.0. The "\% Error" column is the error between the spreadsheet and LLCECALC; errors below one-thousandth of a percent are set to zero. The largest error, about $0.1 \%$, arises due to LLCECALC reporting the "Cat 3 Sum of Fractions" with only three digits. This comparison confirms the accuracy of the algorithms used by LLCECALC.

Table 2-2. Comparison of LLCECALC and Spreadsheet Characterization, Verification Case No. 2.

\begin{tabular}{|l|l|l|l|}
\hline \multicolumn{1}{|c|}{ Compared Feature } & LLCECALC & \multicolumn{1}{|c|}{ Spreadsheet } & \% Error \\
\hline Category 1 Sum of Fractions & 0.87953 & $8.79532 \mathrm{E}-01$ & 0 \\
\hline Category 3 Sum of Fractions & 0.00429 & $4.28519 \mathrm{E}-03$ & 0.112 \\
\hline NRC Class C Sum of Fractions & 1.40372 & $1.40372 \mathrm{E}+00$ & 0 \\
\hline ISB Category 3 Sum of Fractions & $3.00782 \mathrm{e}-04$ & $3.00783 \mathrm{E}-04$ & 0 \\
\hline TRU Waste Sum of Concentrations & 1.40370 & $1.40371 \mathrm{E}+00$ & 0 \\
\hline PE-Ci Curie Content Sum & 0.01335 & $1.33461 \mathrm{E}-02$ & 0.029 \\
\hline PE-Ci Gram Weight Sum & 2.29763 & $2.29763 \mathrm{E}+00$ & 0 \\
\hline PE-Ci Total Coirected Sum & 4.20114 & $4.20115 \mathrm{E}+00$ & 0 \\
\hline Pu-239 Fissile Gram Equivalent Sum & 0.68120 & $6.81197 \mathrm{E}-01$ & 0 \\
\hline Alpha Curie Content Sum & 0.01335 & $1.33461 \mathrm{E}-02$ & 0.029 \\
\hline Heat Generation Rate for Waste Package & $5.78462 \mathrm{e}-04$ & $5.78463 \mathrm{E}-04$ & 0 \\
\hline Transportation Category Sum & 1.55967 & $1.55968 \mathrm{E}+00$ & 0 \\
\hline DE-Ci Total Corrected Sum & 0.00930 & $9.29647 \mathrm{E}-03$ & 0.038 \\
\hline
\end{tabular}

DE-Ci $=$ Dose equivalent curie.

ISB = Interim safety basis.

$\mathrm{PE}-\mathrm{Ci}=$ Plutonium equivalent curie.

NRC = U.S. Nuclear Regulatory Commission.

TRU $=$ Transuranic.

Both this validation for case two and the case one validation of Section 2.1 assume a ${ }^{137} \mathrm{Cs}$ activity as the starting point to confirm the characterization portion of LLCECALC. Section 3.3.5 performs an $\mathrm{i}:$ :dependent calculation, showing that the ${ }^{137} \mathrm{Cs}$ activity used here as a starting point is correct. The characterization confirmation data in Table 2-2 of this section, combined with the process gamma confirmation data in Section 3.3.5, independently validate all the algorithms that are specifically exercised for this case as used in LLCECALC. 


\subsection{VERIFICATION FILE DESCRIPTIONS FOR TWO VERIFICATION CASES}

Volume I: User's Manual presents three verification test cases to judge the proper installation, setup, and operation of both LLCEDATA and LLCECALC. These three test cases are discussed in -' Section 8.0, and results are presented in Volume I, Appendix A. Some specific examples from the first test case are presented in Volume II: Technical Manual, Section 3.0, to demonstrate use of the methodology presented in Volume II, Section 2.0.

Both of the first two test cases are verified independently. Microsoft Excel spreadsheets are created that match the content of the constituents selected for the two test cases. The methodology used to construct the equations used in the Excel spreadsheet come from the documented methodology presented in Volume II: Technical Manual, Section 2.0. These two spreadsheets are in complete agreement with the status and characterization reports of LLCEDATA and LLCECALC. Table 2-3 documents the files used for this validation.

Table 2-3. EDF, AV2, and XLS Files for Independent Validation of Verification Test Case No. 1 and No. 2.

\begin{tabular}{|c|c|}
\hline Filename.ext & What it is and/or does \\
\hline characterizeLY.xIs & $\begin{array}{l}\text { This is the template spreadsheet for the case } 2 . x / s \text { spreadsheet. It is an evolution of the } \\
\text { characterize.x/s spreadsheet template, except that this one incorporates multiple layers. }\end{array}$ \\
\hline characterizeLY,edf & $\begin{array}{l}\text { This is the equipment data file (EDF) that corresponds to the characterizeLY.x/s } \\
\text { spreadsheet. }\end{array}$ \\
\hline Case1.x/s & $\begin{array}{l}\text { This is a spreadsheet created from the characterize.x/s spreadsheet template. It does the } \\
\text { calculations for the characterization process of a one-layer, multi-constituent Long-Length } \\
\text { Contaminated Equipment (LLCE) and waste tank. The }{ }^{137} \text { Cs content was obtained from the } \\
\text { Analyze Gamma Assay Data window after that process was completed by LLCECALC. } \\
\text { Test cases presented in Section } 3.3 \text {. Table 3-2 and Table 3-4, confirm this is a valid } \\
\text { starting point. }\end{array}$ \\
\hline Case1.edf & $\begin{array}{l}\text { This is the EDF that corresponds to the Case1.x/s spreadsheet. It is a 25-ft LLCE with a } \\
20-\mathrm{ft} \text { flange-to-tip dimension. It has the same tank content numbers as the Case1.x/s } \\
\text { spreadsheet, and when processed with the Case1.av2 file in LLCECALC, it should produce } \\
\text { identical results to those shown in the Case1.x/s spreadsheet. }\end{array}$ \\
\hline Case1.av2 & $\begin{array}{l}\text { This is the AV2 file that was processed with the Case } 1 \text {.edf file in the verification and } \\
\text { validation process. It contains unevenly spaced records, backwards motion, zero data, } \\
\text { missing }{ }^{13} \text { Cs data (gaps), negative positions, negative activities, etc. - a real mess by } \\
\text { design. It has a total travel of more than } 20 \mathrm{ft} \text { and so contains adequate information for the } \\
20 \text {-ft flange-to-tip LLCE. }\end{array}$ \\
\hline Case2.x/s & $\begin{array}{l}\text { This is a spreadsheet that does the calculations for the characterization process of a five- } \\
\text { layer LLCE and waste tank. Each layer contains a chemical and radionuclide unique to that } \\
\text { layer as well as }{ }^{137} \mathrm{Cs} \text {. The }{ }^{137} \mathrm{Cs} \text { contents for each layer were obtained from the Analyze } \\
\text { Gamma Assay Data window after that process was completed by LLCECALC. The test } \\
\text { cases presented in Section 3.3. Table } 3-2 \text { and Table } 344 \text {, demonstrates this is an } \\
\text { acceptable starting point. }\end{array}$ \\
\hline Case2.edf & $\begin{array}{l}\text { This is the EDF that corresponds to the Case 2.xIs spreadsheet. It is a 24-ft LLCE with a } \\
19-\mathrm{ft} \text { flange-to-tip dimension. It has the same layer content numbers as the Case2.xls } \\
\text { spreadsheet, and when processed with the Case2.av2 file in LLCECALC, it should produce } \\
\text { identical results to those shown in the Case2.xis spreadsheet. }\end{array}$ \\
\hline Case2.av2 & $\begin{array}{l}\text { This is the AV2 file that was processed with the Case2.edf file in the verification and } \\
\text { validation process. It contains records that are evenly spaced at } 1-\mathrm{ft} \text { increments. The } \\
\text { positions start at } 2 \mathrm{ft} \text { and end at } 23 \mathrm{ft} \text {. Considering start positions, that is a total travel of } \\
22 \mathrm{ft} \text { and so contains adequate information for the } 19-\mathrm{ft} \text { flange-to-tip LLCE. }\end{array}$ \\
\hline
\end{tabular}




\subsection{LLCEDATA AND LLCECALC VALIDATION}

LLCEEDATA and LLCECALC perform two separate and distinct tasks. LLCEDATA is primarily a database extraction tool, allowing the selection, edit, and review of a variety of data. The final product from LLCEDATA is an EDF. LLCECALC takes the EDF and GEA System-produced AV2 file and performs two tasks: process gamma and characterization.

A variety of techniques are used to validate these programs. The databases in LLCEDATA are confirmed by comparing them to independent sources when possible. The process gamma portion of LLCECALC is confirmed by independent test cases as well as comprehensive algorithmic test cases. The process gamma test cases validate the calculation of the ${ }^{137} \mathrm{Cs}$ activity, which is the LLCECALC product after the process gamma phase is complete. The ${ }^{137} \mathrm{Cs}$ activity is the input to the characterization phase of LLCECALC, which is validated in Section 4.0.

\subsection{VALIDATION OF DATABASES USED IN LLCEDATA REQUIRED STEPS}

The main window of LLCEDATA, LLCE Data Selection and Edit, contains four required steps and five optional steps. The required steps allow user interaction for only three of the four steps; the final step allows LLCEDATA to finish creating the EDF. The three main required steps each access data stored in the main database. This section discusses the source and validation of this data.

\subsubsection{LLCE Physical Database}

The first required step of the main selection window, LLCE Data Selection and Edit, requires the user to select and possibly edit the physical data describing an LLCE. The database that contains this data, LLCEPhys, is discussed in Volume II: Technical Manual, Appendix A4, Section A4.9.0. This database lists the physical descriptions of all known LLCE, as follows:

- $\quad$ "H-2" drawing number

- Part number

- Description

- Max. diameter

- Max. length

- Flange-to-tip length

- Container number

- Weight

- Drawing list

- Originating tank farm

- Comments

- Time

- Date.

The data contained in the LLCE Physical database were obtained by conducting a thorough examination of the engineering drawings for LLCE. A comprehensive search of the drawing database was made to identify all active LLCE drawings. The drawings were examined one by one to determine the physical data for each LLCE. The drawings were also independently checked to verify the physical data extracted. It was not possible to extract all data needed to fill the outline above for every LLCE. In these cases, the database entries are zero. Note that this comprehensive database of LLCE physical descriptions is the only known single source available. 


\subsubsection{LLCE Tank Waste Database}

The second required step of the main selection window, LLCE Data Selection and Edit, reguires the user to select and possibly edit the tank waste data. The database that contains this data, TankChar, is discussed in Volume II: Technical Manual, Appendix A4, Section A4.14.0. This database lists information on the constituents of each waste tank, as follows:

$\begin{array}{ll}\text { - } & \text { Constituent } \\ \text { - } & \text { Conemical Abstract Services number } \\ \text { : } & \text { Unit mass } \\ \text { - } & \text { Lnit volume } \\ \text { : } & \text { Thickner number } \\ \text { - } & \text { Specific weight } \\ \text { - } & \text { Data source } \\ \text { - Time } \\ \quad \text { Date } \\ \quad \text { Tank. }\end{array}$

The database was initially constructed by obtaining the tank waste data from the Tank Waste Information Network System (TWINS) database. It is expected that in the future, the code custodian will obtain data from current "Tank Characterization Reports" to update the TankChar database. Currently, not all waste tanks have a Tank Characterization Report; thus, the TWINS database served as the starting point for constructing this table. This initial source of data is also the reason why the current database is limited to only one layer of tank waste. The TWINS database, for example, does not maintain data for layer thickness.

As an alternative to the code custodian being required to update the TankChar database for a specific LLCE activity, the user may edit the tank waste data directly if current knowledge exists that surpasses the tank waste data in the TankChar table. For example, the user would need to do this when the Tank Characterization Report summarizes and discusses the layer thicknesses. If the user does edit the TankChar table, the updated tank waste constituent table is only stored in the EDF specific to the LLCE. While this provides a permanent record of the constituents in the tank waste, the changes will not be reflected in the main TankChar database. The code custodian is the only authorized user to make permanent changes to the main databases. See Volume l: User's Manual, Section 4.2.2 or 4.3.2, for further discussion.

\subsubsection{LLCE Geometry Factors Database}

The third required step of the main selection window, LLCE Data Selection and Edit, requires the user to select and possibly edit the LLCE Geometry Factors. The database that contains this data, LLCEGeom, is discussed in Volume II: Technical Manual, Appendix A4, Section A4.7.0. This database lists the geometry factors for all known LLCE. Due to the nature of this database information, the user is not allowed to directly access the data in this table as is possible with the physical database table described above in Section 3.1.1. If the LLCEGeom table has the geometry factors defined, a prompt appears, notifying the user that the factors are defined when the user selects the LLCE Geometry Factors required option in the LLCE Data Selection and Edit window. If the geometry factors are not defined, as is the case for most LLCE, then the user is required to input the factors directly with the Define LLCE Goometry Correction Factors window discussed in Volume I: User's Manual, Sections 4.2.3 and 4.3.3. 


\subsection{VALIDATION OF DATABASES USED IN LLCEDATA OPTIONAL STEPS}

The main window of LLCEDATA, LLCE Data Selection and Edit, contains four required steps and five optional steps. The optional steps allow the user access to review or edit a variety of data from several databases. These data are used by LLCEDATA to create the EDF and establish the chemical and nuclide limits and constants used to perform the process gamma ${ }^{137} \mathrm{Cs}$ determination and the characterization in LLCECALC. This section will discuss the source and validation of these data.

\subsubsection{Validation of the Waste Container Data Database}

The first optional step of the main selection window, LLCE Data Selection and Edit, allows the user to review and edit the waste container data. The database that contains this data, LLCECont, is discussed in Volume 11: Technical Manual, Appendix A4, Section A4.5.0. This database lists the physica! descriptions of the LLCE containers approved by HNF-SD-TP-SARP-013, Safety Analysis Report for Packaging (Onsite) Long-Length Contaminated Equipment (McCormick 1997), as follows:

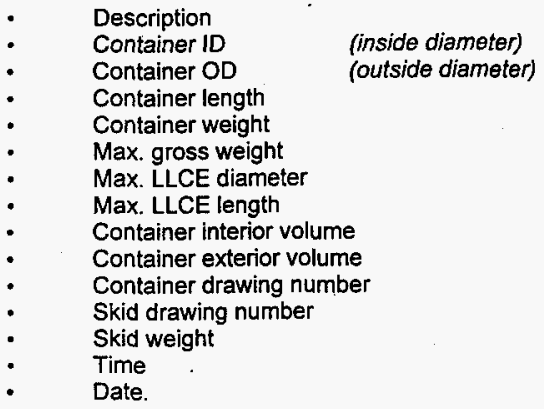

To confirm this database, McCormick (1997) was used to verify the sizes, weights, and volumes.

\subsubsection{Validation of the Radionuclide Constants Data Database}

The second optional step of the main selection window, LLCE Data Selection and Edit, allows the user to review and edit the radionuclide constants. The database that contains this data, LLCENuc, is discussed in Volume 11: Technical Manual, Appendix A4, Section A4.8.0. This database lists the physical constants for the isofopes that are present in the tank waste table. This database contains the following information:

$\begin{array}{ll}- & \text { Isotope name } \\ - & \text { Specific activity (Ci/g) } \\ \text { - } & \text { Half life (years) } \\ \text { Heat generation (W/Ci) } & \text { Alpha indicator } \\ \text { - } \quad \text { TRU indicator } \\ \quad \quad \text { Time } \\ \quad \text { Date } \\ \quad \text { Element abbreviation. }\end{array}$


The verification of this database was accomplished by opening the I/ceinfo.mob file in MS Access ${ }^{5}$ and printing the entire database on a large E-size Hewlitt Packard $755 \mathrm{CM}$ plotter. Each column of data; e.g. specific activity, had a blank column inserted next to it. The data was then reviewed against ant independent source, and any corrections were noted by hand in the blank entry next to the database entry. This allowed for quick identification of necessary corrections and confirmation of those corrections once the database was updated. The reference data used to confirm all database information except for the TRU indicator were taken from RadDecay (Grove Engineering 1994) and Radioactive Decay Data Tables (Kocher 1981). TRU isotopes are defined as isotopes with $Z>92$. The "TRU indicator" used in LLCEDATA is defined using the "TRU waste" definition from U.S. Department of Energy Order 5820.2A (DOE 1988), and the listing was confirmed using the Chart of the Nuclides (GE 1989). The database was verified to be correct after the modifications had been made.

\subsubsection{Validation the Radionuclide Limits Database}

The third optional step of the main selection window, LLCE Data Selection and Edit, allows the user to review and edit the radionuclide limits. The database that contains this data, RadReg, is discussed in Volume II: Technical Manual, Appendix A4, Section A4.11.0. This database lists the characterization limits for the isotopes that are present in the tank waste tabie. This database contains the following information:

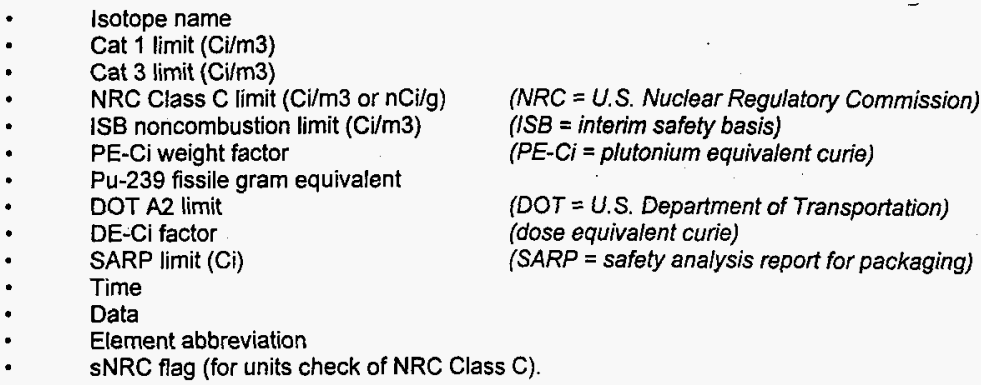

The verification of this database was accomplished by opening the /ceinfo.mdb file in MS Access and printing the entire database on a large E-size Hewlett Packard $755 \mathrm{CM}$ plotter. The data was then reviewed against an independent source, and any corrections were noted by hand on the large printout. This allowed for quick identification of necessary corrections and confirmation of those corrections once the database was updated.

The "DOT A2 limit" values were confirmed with 49 CFR 173, "Shippers--General Requirements for Shipments and Packagings," Subpart I, "Radioactive Materials," $\$ 173.435$, "Table of $A_{1}$ and $A_{2}$ values for radionuclides." The SARP limits for the maximum curie content were confirmed with the most recent SARP (McCormick 1997). HNF-EP-0063-5, Hanford Site Solid Waste Acceptance Criteria (Ellefson 1998) was used to verify the following database entries: Table B-1 for the Pu-239 Fissile Gram Equivalent values; Table A-2, for the Cat 1, Cat 3, and the ISB noricombustion limits; and Table A-1, for the DE-Ci factor. DOENIPP-069, Waste Acceptance Criteria for the Waste Isolation Pilot Plant (DOE-CAO 1996), Appendix A.0, was used to verify the PE-Ci weight factor. The NRC Class $C$ limits and the sNRC unit check flag were verified from 10 CFR 61, "Licensing Requirements for Land Disposal of Radioactive Waste," $\$ 61.55$, "Waste classification," Table 1 and Table 2 . The database was verified to be correct after any modifications were made.

${ }^{5}$ MS Access is a trademark of Microsoft Comoration. 


\subsubsection{Validation of the Chemical Limits Database}

The fourth optional step of the main selection window, LLCE Data Selection and Edit, allows the user to review and edit the chemical limits. The database that contains this data, ChemReg, is discussed in Volume II: Technical Manual, Appendix A4, Section A4.1.0. This database lists the D code limits for heavy metals. This database contains the following information:

- Constituent name

- $\quad$ Chemical Abstracts Service (CAS) number

- D code

- D code limit

- Time

- Date.

The verification of this database was accomplished by comparing each table entry directly with the value specified in the Washington Administrative Code. The D code limits are found in WAC 173-303090 (8)(c). "Toxicity Characteristics List: Maximum Concentration of Contaminants for the Toxicity Characteristic" table. The $\mathrm{D}$ code limit is used for the Dangerous Waste identification. The actual limits used in the ChemReg database are 20 times the D code limit from the table in WAC 173-303-090 (8)(c) as specified in WAC 173-303-090 (8)(a). The justification for the ChemReg database using a limit that is 20 times the D code limit is from WAC 173-303-090 (8)(a) and originates from Test Methods for Evaluating Solid Waste, Physical/Chemical Methods, "Test Method 1311," Section 2.2, "Toxicity Characteristic Leaching Procedure (TCLP)" (EPA 1992).

\subsubsection{Validation of the Valid Gamma List Database}

The fifth and final optional step of the main selection window, LLCE Data Selection and Edit, allows the user to review and edit the valid gamma list. The database that contains this data, LLCEGamma, is discussed in Volume II: Technical Manual, Appendix A4, Section A4.6.0. This database fists the valid gamma isotopes that are accepted from those measured by the GEA System and recorded in the AV2 file. This database contains the following information:

$\begin{array}{ll}\text { - } & \text { Isotope name } \\ \text { - } & \text { Dime } \\ & \text { Date. }\end{array}$

Currently, there is only one isatope listed in this database, ${ }^{137} \mathrm{Cs}$.

\subsubsection{Validation of the Element Database}

Several optional entry windows in LLCEDATA allow the user to select from a list of chemicals or nuclides. The database that contains this listing is called the Element database and is discussed in Volume II: Technical Manual, Appendix A4, Section A4.2.0. This database contains the following information:

$\begin{array}{ll}\text { - } & \text { Description } \\ \text { - } & \text { CAS number } \\ \text { - } & \text { Name } \\ \text { - Formula. }\end{array}$

The entries in this table were verified by comparing them to the entries in CRC Handbook of Chemistry and Physics (CRC 1997). 


\subsection{VALIDATION OF LLCECALC WITH SYNTHETIC DATA}

LLEEDATA and LLCECALC must assess the total contamination of the LLCE and then :characterize this contamination by determining which, if any, of the several category limits for transportation and disposal are exceeded. There are several limitations to the LLCE gamma measurement system (see Volume II: Technical Manual, Section 1.4) and several assumptions in the methodology for obtaining activities for all contaminants needed in the characterization process. The validation work presented here is specific only to the algorithms employed in the software and does not address limitations and assumptions employed in the methodology. That is, the validation process assumes that the methodology and measured data are without error and proceeds to validate the ability of the software to correctly carry out its methodology with the GEA System-supplied measured data as outlined in Volume II: Technical Manual, Section 2.0.

Programs LLCEDATA and LLCECALC were validated with various synthetic data sets designed to test specific components and algorithms. The synthetic data sets were designed to be simple in structure so that hand calculations of final results were easy to obtain for the validation process. Table 3-1 identifies and describes several of the initial validation test cases. Additional cases that validate specific algorithms of both programs are given in later tables. Many supporting files were created during this validation process. These files comprised EDF, AV2, and Excel spreadsheets. The code custodian keeps these verification files in the project folder, available upon request. Copies of files and documentation may be obtained by contacting the Waste Management Federal Services, Inc., Northwest Operations (MMNW) code custodian at 509-376-0610 or the Engineering Unit office at 509-376-7111.

LLCECALC performs two functions. The first, Process Garnma, is to read an AV2 file and correct for any anomalies to the activity data recorded in the file. This process is discussed in detail in Volume II: Technical Manual, Section 2.2. The second phase LLCECALC performs is to take the ${ }^{137} \mathrm{Cs}$ activity calculated in the first phase and basically do two things. First, the radionuclide and chemical content is calculated for the LLCE. Second, the LLCE is checked for characterization limitations imposed by the disposal process via the steps outlined in Volume II: Technical Manual, Section 2.5.

To facilitate the validation of LLCECALC, these two main functions, process gamma and characterization, were separated for testing. Thus, the verification cases presented in this report independently assess LLCECALC's ability to (1) determine the ${ }^{137} \mathrm{Cs}$ activity properly from an AV2 file and (2) perform the correct content calculations and characterization for the LLCE, given a ${ }^{137} \mathrm{Cs}$ activity for the LLCE.

\subsubsection{Discussion of ${ }^{137} \mathrm{Cs}$ Gamma Activity Validation Results}

The validation cases in Table 3-1 are tests of certain LLCECALC program features that are critical to a correct ${ }^{137} \mathrm{Cs}$ gamma activity analysis of an LLCE. The objective of each set appears in column 1, and the synthetic data are described in column 2. All AV2 files are used with the same EDF by LLCECALC. The LLCE chosen is a thermocouple tree retrieved from waste tank AZ-101, Riser 13D. Its tip-to-flange length is $55.646 \mathrm{ft}$.

Table 3-2 contains a summary of results for the $\mathrm{LLCE}{ }^{137} \mathrm{Cs}$ activity validation calculations. Percent differences between hand calculation and LLCECALC results appear in the right hand column. 
HNF-3169, Rev. 0

Table 3-1. Examples of Initial Gamma Analysis Validation.

\begin{tabular}{|l|l|l|}
\hline \multicolumn{1}{|c|}{ Validation Objective } & \multicolumn{1}{|c|}{ Synthetic Data Description } & File Identifier स.AV2) $^{*}$ \\
\hline $\begin{array}{l}\text { Proper statistical weighting of the } \\
\text { three detector activities }\end{array}$ & $\begin{array}{l}\text { Detector activities uniform, but different } \\
\text { for the three detectors along length of } \\
\text { Long-Length Contaminated Equipment } \\
\text { (LLCE) with five sets of statistical error } \\
\text { combinations }\end{array}$ & $\begin{array}{l}\text { stwt1, stwt2, stwt3, } \\
\text { stwt4, stwt4a, stwt5 }\end{array}$ \\
\hline $\begin{array}{l}\text { Recognition of LLCE motion } \\
\text { reversal and proper replacement of } \\
\text { prior data records with final records } \\
\text { for repeat positions }\end{array}$ & $\begin{array}{l}\text { Detector activities uniform and the } \\
\text { same at all positions on LLCE except } \\
\text { for motion reversal intervals }\end{array}$ & Ns/1, rvs/2 \\
\hline $\begin{array}{l}\text { Recognition of gaps in detector } \\
\text { data and proper computation of } \\
\text { interpolated gamma activity }\end{array}$ & $\begin{array}{l}\text { Uniform and identical detector data } \\
\text { prior to gap, increasing by factor of } \\
\text { three after gap, gaps of length 1 ft and } \\
5 \text { ft and two locations along LLCE } \\
\text { length }\end{array}$ & gap1, gap5, gap5a \\
\hline
\end{tabular}

Table 3-2. Comparisons of ${ }^{137} \mathrm{Cs}$ LLCECALC to Hand Calculations.

\begin{tabular}{|c|c|c|c|}
\hline \multirow[b]{2}{*}{ Validation File ID } & \multicolumn{2}{|c|}{ LLCE ${ }^{137}$ Cs Activity (Ci) } & \multirow{2}{*}{$\begin{array}{c}\text { Percent } \\
\text { Difference }\end{array}$} \\
\hline & LLCECALC & $\begin{array}{c}\text { Hand } \\
\text { Calculation }\end{array}$ & \\
\hline stut1.av2 & 0.05646 & 0.0564646 & -.0081 \\
\hline stwt2.av2 & 0.08347 & 0.083469 & .0012 \\
\hline stwt3.av2 & 0.11049 & 0.1104734 & .0150 \\
\hline stut4.av2 & 0.06530 & 0.0652989 & .0017 \\
\hline stut4a.av2 & 0.06530 & 0.0652989 & .0017 \\
\hline stwt5.av2 & 0.08346 & 0.0834690 & -.0108 \\
\hline gap1.av2. & 0.15464 & 0.154646 & -.0039 \\
\hline gap5.av2 & 0.15864 & 0.158646 & -.0039 \\
\hline gap5a.av2 & 0.14393 & 0.143938 & -.00556 \\
\hline nsl1.av2 & 0.04754 & 0.047546 & -.0126 \\
\hline ns/2.av2 & 0.04754 & 0.047546 & -.0126 \\
\hline
\end{tabular}

LLCE $=$ Long-Length Contaminated Equipment.

Table 3-2 for single-layer waste tanks, as well as Table 3-4 for multi-layer waste tanks, independently confirms and validates that the ${ }^{137} \mathrm{Cs}$ activity calculations for the first phase of LLCECALC are correct. Specified ${ }^{137} \mathrm{Cs}$ activities are used as a starting point for most characterization test cases.

3.3.2 Statistically Weighted Average Activity 
The set of synthetic files stwt*av2 was designed to validate the new statistically weighted averaging feature recently added to LLCECALC to improve the way in which the measurement results for the three detectors are combined. The three detector activities, after geometry and shielding corrections, were chosen to be $1,000 \mu \mathrm{Ci} / \mathrm{tt}, 1,500 \mu \mathrm{Ci} / \mathrm{ft}$, and 2,000 $\mu \mathrm{Ci} / \mathrm{ft}$ for detectors No. 1, No. 2, and No. 3, respectively, and for all crane positions. Different sets of \% error values were assigned to each detector activity as shown in Table 3-3.

Table 3-3. Test Cases for Statistically Weighted Average Activity Validation.

\begin{tabular}{|l|c|c|c|}
\hline File Name & Det No. 1 & Det No. 2 & Det No. 3 \\
\hline stwt1 & $1 \%$ & $10 \%$ & $10 \%$ \\
\hline stwt2 & $10 \%$ & $10 \%$ & $10 \%$ \\
\hline stwt3 & $10 \%$ & $10 \%$ & $1 \%$ \\
\hline stwt4 & $2 \%$ & $4 \%$ & $6 \%$ \\
\hline stwt4a* & $2 \%$ & $4 \%$ & $6 \%$ \\
\hline stwt5 & $10 \%$ & $1 \%$ & $10 \%$ \\
\hline
\end{tabular}

"This case has a $0.5-f f$ position offset.

When statistical error is the same for each detector, the statistically weighted average is the same as the simple average of $1,500 \mu \mathrm{Ci} / \mathrm{ft}$ (stwt2). When multiplied by the length of the particular thermocouple tree selected from the equipment database and contained in the EDF, the total LLCE activity for ${ }^{137} \mathrm{Cs}$ is, by hand calculation, equal to $1,500 \mu \mathrm{Ci} / \mathrm{tt} \times 55.646 \mathrm{ft}=83,469 \mu \mathrm{Ci}_{i}$ or $0.083469 \mathrm{Ci}$. When statistical errors are different, the statistically weighted average will move toward the value with the smallest error. For the several combinations of percent statistical errors, the results from LLCECALC and from similar hand calculations as contained in Table 3-2 show near-perfect agreement, validating the statistically weighted averaging feature of the software. There are no systematic trends in the percent difference, and the small average value of this difference indicates the differences are probably due to round-off errors.

\subsubsection{Motion Reversals During LLCE Retrieval}

The set of files $r v s^{*} . a v 2$ was designed to test for proper recognition and treatment of motion reversals for the crane. Such reversals often happen, for various reasons, as the LLCE is retrieved from the waste tank. It is important for the software to update the measured activities as each position is repeated because the last measured activity for a given position is what is needed for the final LLCE activity calculation. File rusl1.av2 contains a 10-ft motion reversal covering crane positions from $10 \mathrm{ft}$ to $20 \mathrm{ft}$. For the reversed motion section, the measured activities are reduced by a factor of 10 from what they are for all other measured crane positions. File $N$ s/2.av2 contains a reversed motion section of the same length but at crane positions from $30 \mathrm{ft}$ to $40 \mathrm{ft}$. LLCECALC successfully recognized the recomputed gamma activity for both cases so that results were in agreement with the hand calculation, as shown in Table 3-2. 


\subsubsection{Physical Gaps in Gamma Data Along LLCE Length.}

The set of files gap*.av2 was designed to test for proper recognition of and correction for gaps in the gamma data that sometimes occur for actual LLCE measurements. Ggap1.av2 contains a 1-ft gap from a crane position of $10 \mathrm{ft}$ to $11 \mathrm{ft}$. The activity for each detector when below the gap (toward the tip of the LLCE) is a factor of three greater than the activity above the gap (toward the mounting flange of the LLCE). These activities are $3,000 \mu \mathrm{Ci} / \mathrm{ft}$ and $1,000 \mu \mathrm{Ci} / \mathrm{ft}$ below and above the gap, respectively. Therefore, the code should, after recognition of the gap, interpolate an intermediate value of $2,000 \mu \mathrm{Ci} / \mathrm{ft}$ for the gap interval. Depending on the width of the gap and its location on the LLCE, differing total ${ }^{137} \mathrm{Cs}$ activities occur. These are easily hand calculated for comparison to the LLCECALC resuit. Gamma data file gap5.av2 has a 5-ft gap starting at the same position as gap1.av2, and gap5a.av2 has a 5-ft gap near the opposite end of the LLCE. All three cases produce test calculations in close agreement with hand calculation as seen in Table 3-2.

\subsubsection{Multiple Layers of Tank Waste}

Several synthetic data files were created to validate the methodology for computing $\operatorname{LLCE}{ }^{137} \mathrm{Cs}$ activity when the equipment has been retrieved from tank waste that is in the form of two or more layers, each having a different set of radionuclide activities assigned in the synthetic database. Although the actual LLCEDATA database does not presently contain multi-layer data, it is expected that such data will be added in the future. Because the gamma measurement system determines only the ${ }^{137} \mathrm{Cs}$ activity along the length of the LLCE, it is necessary to use tank-waste radionuclide ratios to infer other contaminants on the LLCE. A multi-layer tank-waste model will produce a more accurate calculation of these other contaminant activities.

An idealized AV2 file, IIceLY_5.av2, contains ${ }^{137} \mathrm{Cs}$ activity for a particular LLCE that increases uniformly from $1 \mu \mathrm{Ci} / \mathrm{ft}$ to $5 \mu \mathrm{Ci} / \mathrm{ft}$ as crane position increases, covering the full length of the 28-ft-long LLCE. This test file and others are listed in Table 3-5. The EDF validation files for the five multi-layer cases are designated $\| c e L Y^{* *}$.edf and correspond to five layers of tank waste with varying distances from the tip of the LLCE to the bottom of the tank. Each layer contains a different ${ }^{137} \mathrm{Cs}$ activity while the other radionuclide activities are held constant. This results in a different ratio of ${ }^{137} \mathrm{Cs}$ activity to each of the other radionuclides; hence, the total activity associated with each position on the LLCE will be different for different layers, given the same ${ }^{137} \mathrm{Cs}$ activity. These cases then test the basic methodology of assigning contamination activity for each 1 -ft interval of the LLCE for multiple layers of tank waste. The cases also test the ability of LLCECALC to correctly assign radionuclide ratios to position on the LLCE as layer locations change relative to the LLCE.

To verify the algorithms and methodology of LLCECALC for this multi-layer test case, several criteria were identified to be independently confirmed. These include the ${ }^{137} \mathrm{Cs}$ activity determination per layer; the confirmation of several specific Process Gamma steps (e.g., correct use of geometry factor identification at transition points within a layer); and the confirmation of the entire characterization process.

LLCECALC was observed to correctly assign radionuclide ratios to each interval on the LLCE as the layer locations were varied. Appendix B, Section B3.0, shows an Excel spreadsheet that independently calculates the ${ }^{137} \mathrm{Cs}$ activity per layer for the five-layer test case. The spreadsheet is comprised of two sheets. Sheet one calculates the auto-correction factors and is not shown. Sheet two calculates the ${ }^{137} \mathrm{Cs}$ curie content for each layer and shows total ${ }^{137} \mathrm{Cs}$ curie content for the LLCE based on the methodology and algorithms outlined in Volume II, Technical Manual, Section 2.0. Table 3-4 shows a comparison between the ${ }^{137} \mathrm{Cs}$ activity results per layer calculated by LLCECALC and the activity results per layer calculated by the spreadsheet. The spreadsheet confirms that the ${ }^{137} \mathrm{Cs}$ calculations performed by LLCECALC are correct. Comparing the results between the two approaches agrees exactly.

The geometry factor identification at transitions points was an initial bug in the software, and this multi-layer test case was chosen to confirm the removal of the bug. This transition point problem occurs when an LLCE has geometry factors that change within two or more layers or a transition occurs within a 
particular layer. An additional record is needed when this transition occurs. The new record allows the measured activity to be split in two; one part of the record is multiplied by one geometry factor, and the other part of the record is multiplied by the other geometry factor. The algorithm is fully documented in Volume II: Technical Manual, Section 2.3.5. The spreadsheet in Appendix B, Section B3.0, although calculated completely independently of LLCECALC, shows the additional records that were manually created to coincide with the specific record creation mechanism of LLCECALC. The spreadsheet shows "N/A" in the detector readings for the records that were created. These records are necessary as the EDF and AV2 file specify that the LLCE has multiple geometry correction factors that occur within a specific layer. LLCECALC and the spreadsheet must divide the record at the geometry correction factor transition points and adjust the gamma readings for that record. The spreadsheet confirms that the ${ }^{137} \mathrm{Cs}$ calculations performed by LLCECALC are correct.

Table 3-4 for multi-layer waste tanks, as well as Table 3-2 for single-layer waste tanks, independently confirms and validates that the ${ }^{137} \mathrm{Cs}$ activity calculations for the first phase of LLCECALC are correct. Section 4.0 of this document focuses on and documents the validation of the characterization portion of LLCECALC. The validation cases presented in Section 4.0 assume, as a starting point, the correct determination of the ${ }^{137} \mathrm{Cs}$ activity. LLCECALC determines this by the nine-step Process Gamma phase. Section 3.4 contains test cases to further supplement the cases presented in Section 3.3 to verify the AV2 file-reading mechanism of Process Gamma.

Table 3-4. Comparison of LLCECALC and Spreadsheet ${ }^{137} \mathrm{Cs}$ Calculation, Verification Case No. 2.

\begin{tabular}{|l|c|c|c|}
\hline Layer Number & LLCECALC & Spreadsheet & $\%$ Error \\
\hline 1 & $1.17593 \mathrm{e}-04$ & $1.175926 \mathrm{E}-04$ & 0 \\
\hline 2 & $1.14005 \mathrm{e}-04$ & $1.140046 \mathrm{E}-04$ & 0 \\
\hline 3 & $5.52083 \mathrm{e}-05$ & $5.520833 \mathrm{E}-05$ & 0 \\
\hline 4 & $2.27778 \mathrm{e}-05$ & $2.277778 \mathrm{E}-05$ & 0 \\
\hline 5 & $1.26551 \mathrm{e}-04$ & $1.265509 \mathrm{E}-04$ & 0 \\
\hline Total: All Layers & $4.36134 \mathrm{e}-04$ & $4.361343 \mathrm{E}-04$ & 0 \\
\hline
\end{tabular}

\subsection{DISCUSSION OF FILES USED TO VERIFY ${ }^{137}$ CS GAMMA ACTIVITY ALGORITHMS}

\subsubsection{EDFs and Preparatory Gamma Assay Analysis Validation}

The files listed in Table 3-5 are data files that physically describe the LLCE that is processed with the appropriate AV2 files to test and confirm the Gamma Assay File Data Analysis Process. The constituents in the waste tanks of each of these four EDFs are simply aluminum and ${ }^{137} \mathrm{Cs}$. These files were created for the sole purpose of verifying the processes of reading and organizing data in preparation of the waste characterization, not the actual waste characterization. 
Table 3-5. EDFs for Gamma Assay File Data Analysis Process Validation.

\begin{tabular}{|c|c|}
\hline Filename,ext. & What it is and/or does \\
\hline LKIIce11.edf & $\begin{array}{l}\text { This is the data file for an 11-ft flange-to-tip, one-layer Long-Length Contaminated } \\
\text { Equipment (LLCE). It is used in conjunction with numerous AV2 files. }\end{array}$ \\
\hline LKIlce22.edf & $\begin{array}{l}\text { This is the data file for a } 22-f t \text { flange-to-tip, one-layer LLCE. It is used in conjunction } \\
\text { with numerous AV2 files. } \\
\text { Specifically, it has been used to verify that the program deals with the unusual cases } \\
\text { where the total range of positions where AV2 data was collected for the LLCE is } \\
\text { much less than the actual LLCE length. This is the case where there are obviously } \\
\text { large portions of gamma measurements missing. }\end{array}$ \\
\hline LKIlce22LYO.edf & $\begin{array}{l}\text { This is the data file for a } 22-\mathrm{ft} \text { flange-to-tip, five-layer LLCE with the tip of the LLCE } \\
0 \mathrm{ft} \text { from the bottom of the tank. It is used in conjunction with several AV2 files to } \\
\text { confirm that the LLCECALC program properly assigns layers to appropriate records. }\end{array}$ \\
\hline LKIIce22LY3.edf & $\begin{array}{l}\text { This is the data file for a } 22 \text {-ft flange-to-tip, five-layer LLCE with the tip of the LLCE } 3 \\
\text { ft from the bottom of the tank. It is used in conjunction with several AV2 files to } \\
\text { confirm that the LLCECALC program properly assigns layers to appropriate records } \\
\text { when the distance from the tip of the LLCE to the bottom of the tank is different than } \\
\text { the default value of zero. } \\
\text { Some related files: } \\
\text { IICeLY15.edf, I/CeLY25.edf, I/ceLY35.edf, I/ceLY45.edf, }\end{array}$ \\
\hline
\end{tabular}

\subsubsection{Fundamental Process Gamma AV2 File Reading Tests}

The files shown in Table 3-6 contain synthetically created data acquisition cases that specifically test and confirm the fundamental aspects of the Process Gamma portion of LLCECALC. The file names shown in this table reflect the steps LLCECALC performs when the Process Gamma methodology is being performed. These steps are documented in Volume II: Technical Manual, Section 2.3. 
Table 3-6. AV2 Files for Gamma Assay File Data Analysis Process Validation. (2 sheets total)

\begin{tabular}{|c|c|c|}
\hline Filename.ext & What it confirms & Comments \\
\hline LK_1_1to2.av2 & \begin{tabular}{|l} 
- Reads AV2 file data into Rawdata table \\
- Spectrum ID number \\
- Date of record acquisition \\
- Start time for data acquisition \\
- Count time \\
- Crane date and time \\
- Crane position at end time for data acquisition \\
- Nuclide atomic number \\
- Nuclide description \\
- Nuclide activity \\
- Percent error of nuclide activity \\
- Writing Rawdata table information to Gammadata table \\
- Correction of positions in records \\
- Convert crane positions to feet \\
- Take absolute value of positions \\
- Convert activities to curies \\
- Extract correct detector number \\
- Truncate the ID number to last seven digits \\
- Correction of inconsistent and zero crane positions \\
- Set inconsistent (all detectors report non-zero \\
positions) crane positions to the average value \\
- Set zero crane positions (all detectors report zero \\
positions) to the interpolated value based on \\
previous and following values \\
- Interpolation of multiple adjacent zero positions (all \\
detectors report zero)
\end{tabular} & $\begin{array}{l}\text { Used } \\
\text { LKIlce 11.edf } \\
\text { while } \\
\text { processing. }\end{array}$ \\
\hline LK_1_3to6.av2 & $\begin{array}{l}\text { - Writing Gammadata table information to Positions table } \\
\text { - Record number } \\
\text { - End position } \\
\text { - }{ }^{137} \mathrm{Cs} \\
\text { - Time } \\
\text { - Calculation of MIN, MAX, and AVERAGE crane travel } \\
\text { - Correction for multiple adjacent records with same crane } \\
\text { position } \\
\text { - Calculation of crane start positions } \\
\text { - Correction of superseded records (backward motion) } \\
\text { - Reduction of activity for shortened records } \\
\text { - Transformation of crane positions to Long-Length } \\
\text { Contaminated Equipment positions } \\
\text { - Creation of new records for tip or flange gaps } \\
\text { - Application of geometry correction factors for }{ }^{137} \mathrm{Cs}\end{array}$ & $\begin{array}{l}\text { Used } \\
\text { LKIlce11.edf } \\
\text { and } \\
\text { LKIlce22.edf } \\
\text { while } \\
\text { processing. }\end{array}$ \\
\hline LK_1_3to6a.av2 & $\begin{array}{l}\text { - Calculation of detector shielding correction factors } \\
\text { - Application of detector shielding correction factors }\end{array}$ & $\begin{array}{l}\text { Documented in } \\
\text { Section } 3.1 .4 \text { of } \\
\text { VII of this } \\
\text { report. }\end{array}$ \\
\hline
\end{tabular}


Table 3-6. AV2 Files for Gamma Assay File Data Analysis

Process Validation. (2 sheets total)

\begin{tabular}{|l|l|l|}
\hline \multicolumn{1}{|c|}{ Filename.ext } & \multicolumn{1}{|c|}{ What it confirms } & \multicolumn{1}{|c|}{ Comments } \\
\hline LK_1_3to6b.av2 & $\begin{array}{l}\text { Correction for multiple adjacent records with same crane } \\
\text { position as } L K \text { 1_3to6.av2, however, this confirms that the } \\
\text { program ignores other records with the same crane position that } \\
\text { are not adjacent. }\end{array}$ & \\
\hline LK_1_7to8.av2 & $\begin{array}{l}\text { - Writing }{ }^{137} \text { Cs activity and percent error from Gammadata table } \\
\text { to Positions table } \\
- \text { Setting negative activities to zero } \\
- \text { Conversion of activity to Ci/ft (divide by length of } \\
\text { travel) }\end{array}$ & $\begin{array}{l}\text { Used } \\
\text { LKIlce22.edf } \\
\text { while } \\
\text { processing. }\end{array}$ \\
& $\begin{array}{l}\text { - Identification of }{ }^{137} \text { Cs measurement gaps } \\
\text { - Creation of new records for these }{ }^{137} \text { Cs measurement gaps } \\
\text { - Combination of adjacent records that have no }{ }^{137} \text { Cs } \\
\text { measurements into one record } \\
\text { - Estimation of }{ }^{137} \text { Cs activity for the above determined } \\
\text { measurement gaps } \\
\text { - Appropriate assignment of layers to records } \\
\text { - Creation of new records when layer change point falls in the } \\
\text { middle of a record }\end{array}$ & $\begin{array}{l}\text { Documented in } \\
\text { Volume II, } \\
\text { Section 3.1.2, } \\
\text { of this } \\
\text { document. }\end{array}$ \\
\hline LK_1_9.av2 & $\begin{array}{l}\text { - Weighted averaging of the three detector readings and } \\
\text { storing the average in the average field of the Positions table } \\
\text { - Summation of total activities for each layer and all layers } \\
\text { combined }\end{array}$ & $\begin{array}{l}\text { Used } \\
\text { LKllce22LY0. } \\
\text { edf while } \\
\text { processing. }\end{array}$ \\
\hline
\end{tabular}




\subsubsection{Specific Tests to Confirm Removal of Intermediate Bugs}

The files listed in Table 3-7 were created to test and verify a specific step of the Gamma Asssay File Data Annalysis Process that was previously a bug.

Table 3-7. Small Gap AV2 Files for Gamma Assay File Data Analysis Process Validation.

\begin{tabular}{|l|l|}
\hline \multicolumn{1}{|c|}{ Filename.ext } & \multicolumn{1}{|c|}{ What it tests } \\
\hline LKsimp.av2 & That the program ignores unreasonably small gaps in position. \\
\hline LKsimp00.av2 & $\begin{array}{l}\text { That when the start position of the first record happens to be calculated as zero, } \\
\text { this zero does not interfere with the zeros that are used as flags for backward } \\
\text { motion. } \\
\text { Backward motion flag has been changed to -99. }\end{array}$ \\
\hline LKsimp01.av2 & $\begin{array}{l}\text { That when there are both zero and non-zero positions recorded for a unique } \\
\text { record ID number, the program sets all of these positions to the average of the } \\
\text { non-zero positions. }\end{array}$ \\
\hline LKsimp02.av2 & $\begin{array}{l}\text { That when the average distance between the positions is much less than one } \\
\text { foot, the program can still function. In this case the average distance is } \\
\text { approximately half of a foot. } \\
\text { The upper and lower limits of a valid record length, 0.8 and 1.5, explain what } \\
\text { happens when this AV2 file is processed. }\end{array}$ \\
\hline LKsimpFT.av2 & $\begin{array}{l}\text { That the program looks at the largest position reported for not only the highest- } \\
\text { numbered detector but also all the detectors in determining if the positions are in } \\
\text { feet or thousandths of a foot. }\end{array}$ \\
\hline LKsmpFT2.av2 & $\begin{array}{l}\text { That the program correctly determines if it should divide the positions by 1000 } \\
\text { When there is only one record for detector No. 3 with a position of 200. }\end{array}$ \\
\hline LKsmpFT3.av2 & $\begin{array}{l}\text { That the program correctly determines if it should divide the positions by 1000 } \\
\text { when the largest position in the AV2 file is reported for detector No. 1 } \\
\text { (Record 12100). }\end{array}$ \\
\hline
\end{tabular}




\subsubsection{Verification of Multi-Layer Assignments}

The files listed in Table 3-8 were created for the specific purpose of verifying that LLCECALC correctly aśsigńs layers to the gamma assay data records when there are multiple layers in a waste tank. This was in response to a bug earlier identified with the files $L K \| l / c e 22 L Y O$.edf and $L K I I c e 22 L Y 3$. edf.

Table 3-8. EDF and AV2 Files for Multi-Layer Validation.

\begin{tabular}{|c|c|}
\hline Filename.ext & What it is and/or does \\
\hline IIceLY_5.av2 & $\begin{array}{l}\text { This is a straightforward, basically perfect and ideal AV2 file that contains a data } \\
\text { record for every detector at even } 1 \text {-ft increments, ranging from an end crane } \\
\text { position of } 2 \mathrm{ft} \text { to } 29 \mathrm{ft} \text {. This results in a total travel distance of } 28 \mathrm{ft} \text { when } \\
\text { considering start positions. The Long-Length Contaminated Equipment (LLCE) } \\
\text { defined in the five equipment data files (EDF) listed below have a flange-to-tip } \\
\text { dimension of } 27.5 \mathrm{ft} \text {, so this AV2 file has enough data to cover the entire length } \\
\text { of the LLCE. Also, the activities range from one to five as the crane positions } \\
\text { increase. }\end{array}$ \\
\hline IlceLY15.edf & $\begin{array}{l}\text { This is an LLCE data file that defines an LLCE in a five-layered waste tank. } \\
\text { Each waste layer is } 5 \mathrm{ft} \text { thick and has a chemical, aluminum, and a radionuclide, } \\
{ }^{137} \mathrm{Cs} \text {, defined for each layer. Arbitrary activities were entered for each layer, but } \\
\text { for the }{ }^{137} \mathrm{Cs} \text {, the activity was increased as the layers increased. The rest of } \\
\text { these EDFs have these same characteristics. The difference is in the distance } \\
\text { from the tip of the LLCE to the bottom of the tank. This file specifies that this } \\
\text { distance is } 2.5 \mathrm{ft} \text {. }\end{array}$ \\
\hline IIceLY25.edf & $\begin{array}{l}\text { Same as } / / C e L Y 15 . e d f \text { except the distance from the tip of the LLCE to the bottom } \\
\text { of the tank is specified as } 7.5 \mathrm{ft} \text {. Therefore, there should be no records assigned } \\
\text { to layer one, which is no higher than } 5 \mathrm{ft} \text { from the bottom of the tank. }\end{array}$ \\
\hline IlceLY35.edf & $\begin{array}{l}\text { Same as } / / C e L Y 15 . e d f \text { except the distance from the tip of the LLCE to the bottom } \\
\text { of the tank is specified as } 12.5 \mathrm{ft} \text {. Therefore, there should be no records } \\
\text { assigned to layers one and two, which are no higher than } 10 \mathrm{ft} \text { from the bottom } \\
\text { of the tank. }\end{array}$ \\
\hline IIceLY45.edf & $\begin{array}{l}\text { Same as } / / \mathrm{ce} L Y 15 . e d f \text { except the distance from the tip of the LLCE to the bottom } \\
\text { of the tank is specified as } 17.5 \mathrm{ft} \text {. Therefore, there should be no records } \\
\text { assigned to layers one, two or three, which are no higher than } 15 \mathrm{ft} \text { from the } \\
\text { bottom of the tank. }\end{array}$ \\
\hline llceLY55.edf & $\begin{array}{l}\text { Same as } / / C e L Y 15 . e d f \text { except the distance from the tip of the LLCE to the bottom } \\
\text { of the tank is specified as } 22.5 \mathrm{ft} \text {. Therefore, there should be no records } \\
\text { assigned to layers one, two, three, or four, which are no higher than } 20 \mathrm{ft} \text { from } \\
\text { the bottom of the tank. }\end{array}$ \\
\hline
\end{tabular}




\subsubsection{Verification for Shielding Correction Factors}

Correct auto-calculation of the shielding correction factors and the correct use of the defaults and IIcecalc ini-file-defined shielding correction factors, whose methodology is discussed in Volume II: Technical Manual, Section 2.3.6, can be verified with the files shown in Table 3-9. These files were created to verify the removal of a specific software bug.

Table 3-9. EDF and AV2 Files for Validating Shielding Correction:Factors.

\begin{tabular}{|c|c|}
\hline Filename.ext & What it is and/or does \\
\hline$L K 27$ 5.edf & $\begin{array}{l}\text { This is basically a duplicate of IlceLY75.edf except that the geometry correction factors for all } \\
\text { detectors are set to } 1.0 \text { so that changes to the activities are only a result of the shielding } \\
\text { factors. }\end{array}$ \\
\hline LKshield.av2 & $\begin{array}{l}\text { This file was created by editing the I/CeLY_5.av2 file and removing } 2 / 3 \text { rds of the records so } \\
\text { that there is only one detector measurement for each record ID rather than the usual three. } \\
\text { This ensures that there are no records where the activities are reported for two or more } \\
\text { detectors so that they can be compared and thus calibrated. In this case then, LLCECALC } \\
\text { should not use the auto-calibrated values, but should use the current program default values } \\
\text { (default and ini both confirmed). } \\
\text { This test case confirmed that if both the auto-calculated and ini default shielding factors are } \\
\text { not used, then the program default values are used correctly. }\end{array}$ \\
\hline LKshield12.av2 & $\begin{array}{l}\text { This is similar to LKshield.av2 except there is one record (ID No. } 1000080 \text { with end crane } \\
\text { position } 8000 \text { ) where there is a measurement for both detector No. } 1 \text { and No. } 2 \text { in order to test } \\
\text { the calibration calculation of the shielding correction factor for detector No. } 2 \text {. }\end{array}$ \\
\hline LKshield13.av2 & $\begin{array}{l}\text { This is similar to LKshield.av2 except there is one record (ID No. } 1000080 \text { with end crane } \\
\text { position } 8000 \text { ) where there is a measurement for both detector No. } 1 \text { and No. } 3 \text { in order to test } \\
\text { the calibration calculation of the shielding correction factor for detector No. } 3 \text {. }\end{array}$ \\
\hline LKshield23.av2 & $\begin{array}{l}\text { This is similar to LKshield.av2 except there is one record (ID No, } 1000090 \text { with end crane } \\
\text { position } 9000 \text { ) where there is a measurement for both detector No. } 2 \text { and No. } 3 \text { in order to test } \\
\text { the calibration calculation of the shielding correction factor for detector No. } 3 \text {. }\end{array}$ \\
\hline autocalc.xis & $\begin{array}{l}\text { This spreadsheet performs the auto-correction factor calculations according to the algorithm } \\
\text { specified in Volume II: Technical Manual, Section } 2.2 .6 \text {. The spreadsheet verifies that } \\
\text { LLCECALC correctly calculates the auto-correction factors. The spreadsheet is set up to } \\
\text { process information found in the Gammadata table, from the EDF, directly after step } 5 \text { of the } \\
\text { Gamma Assay File Data Analysis Process is complete. The specific case that this } \\
\text { spreadsheet examines is the first verification case, c1_1layer, from Volume I: User's Manual, } \\
\text { Section 8.1. }\end{array}$ \\
\hline autocalc2.x/s & $\begin{array}{l}\text { This spreadsheet verifies the LLCECALC }{ }^{137} \text { Cs curie content calculations. Specifically, this } \\
\text { spreadsheet examines verification case No. } 2 \text { of Volume I: User's Manual, Section } 8.2 \text {, the } \\
\text { c2 5layer case. Excel sheet } 1 \text { is the same format as the AutoCalc.x/s spreadsheet and } \\
\text { calculates the auto-correction factors for this five-layer case. Sheet } 2 \text { calculates the }{ }^{137} \mathrm{Cs} \\
\text { curie content for each layer and the total }{ }^{137} \mathrm{Cs} \text { curie content for the LLCE. To perform this } \\
\text { independent confirmation, the algorithms and methodology outlined in Volume II: Technical } \\
\text { Manual, Section } 2.2 \text {, was used to construct the spreadsheet. } \\
\text { This spreadsheet confirms the }{ }^{137} \text { Cs calculations that LLCECALC reports for verification case } \\
\text { No. } 2 \text { from the user's manual. Results are presented in Table } 3-4 \text { and Appendix B, } \\
\text { Section B3.0. }\end{array}$ \\
\hline
\end{tabular}




\subsection{LLCE WASTE CHARACTERIZATION VALIDATION}

When LLCECALC is finished with phase one, process gamma, the characterization activity comprises 11 steps. These steps are verified with the files discussed in this section. Numerous files were used to verify the first 3 steps (see Section 4.1). One AV2 file, characterize.av2, was created and used for verification of the remaining steps, 4 to 11 . The data in this AV2 file was created synthetically, so the symmetry and organization of the data records in this file should not be expected in actual field-acquired data files.

The numerous *.x/s files are Microsoft Excel spreadsheets that are based on the template spreadsheet characterize.x/s. Each spreadsheet has parameters entered so that the calculations produce results that verify an individual characterization process of the many incorporated into the LLCE Waste Characterization Process. These parameters specify such things as what constituents are in the waste tank, how much of each constituent is in the tank, the mass of the LLCE, and the waste container internal volume. Information about each of the constituents is also taken from appropriate database tables specified at the top of the spreadsheet columns. This information includes numerous limits, factors, and other classifications of the constituents.

In verifying an individual characterization process; e.g., the NRC Class $C$ limit, a spreadsheet is manipulated until the value in question is slightly smaller than the classification boundary for that value. This spreadsheet is named with an abbreviation of the classification in question and ends in the letters LO.x/s. For every LO.xIs spreadsheet there is a corresponding HI.x/s spreadsheet named with the same abbreviation, which is manipulated until the value in question is slightly larger than the classification boundary for that value.

Once these two spreadsheets are complete, a corresponding EDF, both in name and constituent content, is created using LLCEDATA and is processed in conjunction with the characterize.av2 file in LLCECALC. When prompted, the LLCECALC program defaults are used. The resulting LLCECALC constituent characterization and classification of the LLCE waste, as output to the status report, are checked against the values generated by the spreadsheet; thus, the LLCE Waste Characterization Process is verified. During this verification process, the shielding correction factors, defined in the Ilcecalc.ini file, are all set equal to 1.0. This disabled the auto-calculated shielding correction factor calculations, which is normally the program default. The verification of the auto-calculated shielding correction factors is discussed in Section 3.2.4.

\subsection{LLCECALC CHARACTERIZATION VERIFICATION, STEPS 1-3}

Table 4-1 shows the files used to verify the first 3 steps. 
Table 4-1. EDF, AV2, and XLS Files for Steps 1-3

Characterization Validation. (2 sheets total)

\begin{tabular}{|c|c|}
\hline Filenam̄è.ext & What it is and/or does \\
\hline characterize av2 & $\begin{array}{l}\text { An ideal AV2 file that is processed in conjunction with each of the EDFs used to } \\
\text { verify the entire LLCE Waste Characterization Process. It has data that spans } \\
5 \mathrm{ft} \text { in even } 1 \text {-ft increments. All of the }{ }^{137} \mathrm{Cs} \text { activities reported in this file are } 1 \mu \mathrm{Ci} \text {. }\end{array}$ \\
\hline characterize.x/s & $\begin{array}{l}\text { This is the template of the following spreadsheets, all files with the ".x/s extension. } \\
\text { It carries out the calculations for the entire characterization process and can be } \\
\text { used to verify LLCECALC's calculations. It is set up to process a one-layer LLCE } \\
\text { and tank. It should be noted that this template spreadsheet has the most updated } \\
\text { features, formulas, and functions of all the spreadsheets and so should be used } \\
\text { as the template for any new spreadsheets created. }\end{array}$ \\
\hline characterize.edf & This is the EDF that corresponds to the characterize.x/s spreadsheet. \\
\hline SARP_LO.X/s & $\begin{array}{l}\text { This is a spreadsheet where the values used result in the content of two of the } \\
\text { radionuclides slightly smaller than their SARP (McCormick 1997) limits. }\end{array}$ \\
\hline SARP_HI.XIS & $\begin{array}{l}\text { This is a spreadsheet where the values used result in the content of two of the } \\
\text { radionuclides slightly larger than their SARP (McCormick 1997) limits. }\end{array}$ \\
\hline Cat1LO.x/s & $\begin{array}{l}\text { This is a spreadsheet where the values used result in a Cat } 1 \text { sum of fractions } \\
\text { slightly smaller than } 1 \text {, the classification boundary for Cat } 1 \text { waste. }\end{array}$ \\
\hline CattHI.x/s & $\begin{array}{l}\text { This is a spreadsheet where the values used result in a Cat } 1 \text { sum of fractions } \\
\text { slightly larger than } 1 \text {, the classification boundary for Cat } 1 \text { waste. }\end{array}$ \\
\hline Cat3LO.x/s & $\begin{array}{l}\text { This is a spreadsheet where the values used result in a Cat } 3 \text { sum of fractions } \\
\text { slightly smaller than } 1 \text {, the classification boundary for Cat } 3 \text { waste. }\end{array}$ \\
\hline Cat3HI.x/s & $\begin{array}{l}\text { This is a spreadsheet where the values used result in a Cat } 3 \text { sum of fractions } \\
\text { slightly larger than } 1 \text {, the classification boundary for Cat } 3 \text { waste. }\end{array}$ \\
\hline NRCA_LO.X/s & $\begin{array}{l}\text { This is a spreadsheet where the values used result in an NRC sum of fractions } \\
\text { slightly smaller than } 0.1 \text {, the classification boundary for NRC Class AVlass C } \\
\text { waste. }\end{array}$ \\
\hline NRCA_HI.XIS & $\begin{array}{l}\text { This is a spreadsheet where the values used result in an NRC sum of fractions } \\
\text { slightly larger than } 0.1 \text {, the classification boundary for NRC Class AVClass C } \\
\text { waste. }\end{array}$ \\
\hline NRC_LO.XIs & $\begin{array}{l}\text { This is a spreadsheet where the values used result in an NRC sum of fractions } \\
\text { slightiy smaller than } 1 \text {, the classification boundary for NRC Class C waste. }\end{array}$ \\
\hline NRC_HI.X/s & $\begin{array}{l}\text { This is a spreadsheet where the values used result in an NRC sum of fractions } \\
\text { slightly larger than 1, the classification boundary for NRC Class C waste. }\end{array}$ \\
\hline combust_LO.x/s & $\begin{array}{l}\text { This is a spreadsheet where the values used result in a noncombustible sum of } \\
\text { fractions slightly smaller than } 1 \text {, the classification boundary for noncombustible } \\
\text { waste. }\end{array}$ \\
\hline combust_HI.x/s & $\begin{array}{l}\text { This is a spreadsheet where the values used result in a noncombustibie sum of } \\
\text { fractions slightly larger than } 1 \text {, the classification boundary for noncombustible } \\
\text { waste. }\end{array}$ \\
\hline SARP_LO.edf & This is the EDF that corresponds to the SARP_LO.x/s spreadsheet. \\
\hline
\end{tabular}


Table 4-1. EDF, AV2, and XLS Files for Steps 1-3

Characterization Validation. (2 sheets total)

\begin{tabular}{|l|l|}
\hline \multicolumn{1}{|c|}{ Filename.ext } & \multicolumn{1}{c|}{ What it is and/or does } \\
\hline SARP_HI.edf & This is the EDF that corresponds to the SARP_HI.x/s spreadsheet. \\
\hline Cat1LO.edf & This is the EDF that corresponds to the Cat1LO.x/s spreadsheet. \\
\hline Cat1HI.edf & This is the EDF that corresponds to the Cat1HI.x/s spreadsheet. \\
\hline Cat3LO.edf & This is the EDF that corresponds to the Cat3LO.x/s spreadsheet. \\
\hline Cat3HI.edf & This is the EDF that corresponds to the Cat3HI.xis spreadsheet. \\
\hline NRCA_LO.edf & This is the EDF that corresponds to the NRCA_LO.x/s spreadsheet. \\
\hline NRCA_HI.edf & This is the EDF that corresponds to the NRCA_HI.x/s spreadsheet. \\
\hline NRC_LO.edf & This is the EDF that corresponds to the NRC_LO.x/s spreadsheet. \\
\hline NRC_HI.edf & This is the EDF that corresponds to the NRC_HI.xIs spreadsheet. \\
\hline combust_LO.edf & This is the EDF that corresponds to the COmbust_LO.xIs spreadsheet. \\
\hline combust_HI.edf & This is the EDF that corresponds to the COmbust_HI.x/s spreadsheet. \\
\hline
\end{tabular}

EDF = Equipment data file.

LLCE $=$ Long-Length Contaminated Equipment.

SARP = Safety analysis report for packaging

McCormick, W. A., 1997, Safety Analysis Report for Packaging (Onsite) Long-Length Contaminated Equipment Transport System, HNF-SD-TP-SARP-013, Rev. 0, prepared by Waste Management Federal Services, Inc., Northwest Operations for Fluor Daniel Hanford, Inc., Richland, Washington. 


\subsection{LLCECALC CHARACTERIZATION VERIFICATION, STEP 4}

The forth step performed by the LLCE Waste Characterization Process of LLCECALC is the Calculation for TRU Waste. The algorithms used by LLCECALC are documented in Volume II: Technical Manual, Section 2.5.4. The files listed below in Table 4-2 verify the TRU calculations using a similar manner as that specified above for steps 1 through 3 .

Table 4-2. EDF, AV2, and XLS Files for Step 4, Transuranic Validation.

\begin{tabular}{|c|c|}
\hline Filename.ext & What it is and/or does \\
\hline SuspectTRU_LO.x/s & $\begin{array}{l}\text { This is a spreadsheet where the values used result in the sum of the } \\
\text { transuranic (TRU) isotope concentrations being slightly smaller than } 0.85 \text {, } \\
\text { the classification boundary for suspect TRU waste as defined in the } \\
\text { licecalc.ini file for this test case. }\end{array}$ \\
\hline SuspectTRU_HI.xis & $\begin{array}{l}\text { This is a spreadsheet where the values used result in the sum of the TRU } \\
\text { isotope concentrations being slightly larger than } 0.85 \text {, the classification } \\
\text { boundary for suspect TRU waste as defined in the llcecalc.ini file for this test } \\
\text { case. }\end{array}$ \\
\hline TRU_LOXIS & $\begin{array}{l}\text { This is a spreadsheet where the values used result in the sum of the TRU } \\
\text { isotope concentrations being slightly smaller than } 1.0 \text {, the classification } \\
\text { boundary for TRU waste. }\end{array}$ \\
\hline TRU_HI.x/s & $\begin{array}{l}\text { This is a spreadsheet where the values used result in the sum of the TRU } \\
\text { isotope concentrations being slightly larger than 1.0, the classification } \\
\text { boundary for TRU waste. }\end{array}$ \\
\hline S_TRU_noini_LO.x/s & $\begin{array}{l}\text { This is a spreadsheet where the values used result in the sum of the TRU } \\
\text { isotope concentrations being slightly smaller than } 0.90 \text {, the default } \\
\text { classification boundary for suspect TRU waste when there is no suspect } \\
\text { TRU classification boundary defined in the llcecalc.ini file. }\end{array}$ \\
\hline$S_{-} T R U_{-}$noini_HI.xIs & $\begin{array}{l}\text { This is a spreadsheet where the values used result in the sum of the TRU } \\
\text { isotope concentrations being slightly larger than } 0.90 \text {, the default } \\
\text { classification boundary for suspect TRU waste when there is no suspect } \\
\text { TRU classification boundary defined in the licecalc.ini file. }\end{array}$ \\
\hline SuspectTRU_LO.edf & $\begin{array}{l}\text { This is the equipment data file (EDF) that corresponds to the } \\
\text { SuspectTRU_LO.x/s spreadsheet. }\end{array}$ \\
\hline SuspectTRU_Hl.edf & This is the EDF that corresponds to the SuspectTRU_HI.x/s spreadsheet. \\
\hline$T R U_{-} L O . e d f$ & This is the EDF that corresponds to the TRU_LO.x/s spreadsheet. \\
\hline$T R U \_H I . e d f$ & This is the EDF that corresponds to the TRU_HI.x/s spreadsheet. \\
\hline S_TRU_noini_LO.edf & This is the EDF that corresponds to the $S_{-} T R U_{-}$noini_LO.xis spreadsheet. \\
\hline S_TRU_noini_HI.edf & This is the EDF that corresponds to the $S_{-} T R U_{-}$noini_HI.x/s spreadsheet. \\
\hline
\end{tabular}




\subsection{LLCECALC CHARACTERIZATION VERIFICATION, STEPS 5-11}

The remaining steps performed by the LLCE Waste Characterization Process of LLCECALC are confirmed by the files shown in Table 4-3. The algorithms used by LLCECALC are documented in Volume II: Technical Manual, Sections2.5.5 through 2.5.11. These files verify steps 5 to 11 in a similar manner to that specified above for steps 1 through 3 or step 4.

Table 4-3. EDF, AV2, and XLS Files for Steps 5-11, Characterization Validation.

\begin{tabular}{|c|c|}
\hline Filename.ext & What it is and/or does \\
\hline$P E \_C i \_O . x / S$ & $\begin{array}{l}\text { This is a spreadsheet where the values used result in a plutonium equivalent curie } \\
\text { (PE-Ci) total slightly smaller than } 35 \mathrm{~g} \text {, the critical boundary for PE-Ci. }{ }^{239} \mathrm{Pu} \text { fissile } \\
\text { gram equivalent (FGE) and Alpha Curie Content calculations can be verified with } \\
\text { this spreadsheet as well. }\end{array}$ \\
\hline PE_Ci_HI.X/s & $\begin{array}{l}\text { This is a spreadsheet where the values used result in a PE-Ci total slightly larger } \\
\text { than } 35 \mathrm{~g} \text {, the critical boundary for PE-Ci. }\end{array}$ \\
\hline Heat_LO.xis & $\begin{array}{l}\text { This is a spreadsheet where the values used result in a heat generation rate } \\
\text { slightly smaller than } 0.1 \mathrm{~W} / \mathrm{ft}^{3} \text {, the critical number for heat generation classification. }\end{array}$ \\
\hline Heat_HI.xis & $\begin{array}{l}\text { This is a spreadsheet where the values used result in a heat generation rate } \\
\text { slightly larger than } 0.1 \mathrm{~W} / \mathrm{ft}^{3} \text {, the critical number for heat generation classification. }\end{array}$ \\
\hline TRANSA_LO.x/S & $\begin{array}{l}\text { This is a spreadsheet where the values used result in a transportation category } \\
\text { sum of fractions slightly smaller than } 1 \text {, the classification boundary for Type } A \text { ) } \\
\text { Type B. Dose equivalent curie (DE-Ci) should not be calculated for this case. }\end{array}$ \\
\hline TRANSA_HI.x/s & $\begin{array}{l}\text { This is a spreadsheet where the values used result in a transportation category } \\
\text { sum of fractions slightly larger than } 1 \text {, the classification boundary for Type AV } \\
\text { Type B. DE-Ci should be calculated for this case. }\end{array}$ \\
\hline TRANSB_LO.XIS & $\begin{array}{l}\text { This is a spreadsheet where the values used result in a transportation category } \\
\text { sum of fractions slightly smaller than } 3000 \text {, the classification boundary for Type } B \text {, } \\
\text { highway route controlled quantity (HRCQ). }\end{array}$ \\
\hline TRANSB_HI.x/s & $\begin{array}{l}\text { This is a spreadsheet where the values used result in a transportation category } \\
\text { sum of fractions slightly larger than } 3000 \text {, the classification boundary for Type } B \text {, } \\
\text { HRCQ. }\end{array}$ \\
\hline Dcodes.xis & $\begin{array}{l}\text { This is a spreadsheet where the values used result in one chemical D code } \\
\text { surpassed and one D code undermined. }\end{array}$ \\
\hline PE_Ci_LO.edf & $\begin{array}{l}\text { This is the equipment data file (EDF) that corresponds to the PE_Ci_LO.xls } \\
\text { spreadsheet. }\end{array}$ \\
\hline PE_Ci_HI.edf & This is the EDF that corresponds to the PE_Ci_HI.x/s spreadsheet. \\
\hline Heat_LO.edf & This is the EDF that corresponds to the Heat_LO.x/s spreadsheet. \\
\hline Heat_HI.edf & This is the EDF that corresponds to the Heat_HI.xIs spreadsheet. \\
\hline TRANSA_LO.edf & This is the EDF that corresponds to the TRANSA_LO.x/s spreadsheet. \\
\hline TRANSA_HI.edf & This is the EDF that corresponds to the TRANSA_HI.xis spreadsheet. \\
\hline TRANSB_LO.edf & This is the EDF that corresponds to the TRANSB_LO.x/s spreadsheet. \\
\hline TRANSB_HI.edf & This is the EDF that corresponds to the TRANSB_HI.x/s spreadsheet. \\
\hline Dcodes.edf & This is the EDF that corresponds to the Dcodes.xis spreadsheet. \\
\hline
\end{tabular}




\subsection{CONFIGURATION CONTROL}

\subsection{ARCHİVAL STORAGE AND RECORDS}

The date and time stamp for the LLCEDATA for Windows Version 1.0 executable file is $08 / 20 / 98$, $12: 38$ p.m. The date and time stamp for the LLCECALC for Windows Version 1.0 executable file is 08/24/98, 7:02 a.m. The source and run files documentation and the verification and validation files for LLCEDATA and LLCECALC are archived on two write-only compact disks (CD) (EBU-CD-006) stored at records retention areas maintained by WMNW. The code custodian also maintains a copy of the CD.

A copy of an installation $C D$ with installation files and the user's manual can be obtained from the code custodian in the EBU at WMNW. Please call 509-376-0610 or 509-376-7111.

Documentation for the LLCEDATA and LLCECALC for Windows Version 1.0 will be released into the Hanford Records Management System and maintained by Document Control 509-376-9177. The LLCEDATA and LLCECALC sottware CDs (EBU-CD-006) will be located in the permanent files at WMNW.

Quality assurance (QA) records will be maintained in accordance with the Project Hanford Management Contractor QA program as described in HNF-MP-599. At the completion of the development project and subsequent changes, QA records, including software, will be transferred to the Project Hanford Management Contractor customer for storage as the official QA records. The code custodian may maintain working copies.

\subsection{BACKUP AND RECOVERY}

Upon completion of a version of the LLCEDATA and LLCECALC for Windows, the code custodian will back up all files for the code and write them to two CDs for permanent storage. The code custodian will also maintain a copy of the CDs.

\subsection{DISTRIBUTION}

The code custodian will maintain a file of all the LLCEDATA and LLCECALC for Windows users. Upon completion of a new version of the LLCEDATA and LLCECALC for Windows, all users will be notified of the availability of the new version.

Copies of LLCEDATA and LLCECALC for Windows can be obtained by calling the code custodian at 509-376-0610 or the Engineering secretary at 509-376-7111. Copies of the manuals are available through Document Control.

\subsection{CONFIGURATION MANAGEMENT PLAN}

The following steps are recommended for software changes or identified problems.

1. Identify the changes that are requested or the problem in the program. Submit a description of the change or problem to the code custodian in the Engineering Business Unit of WMNW using the form provided in Appendix A or in writing per HNF-PRO-469, Software Practices - Change Request and Problem Report. The code custodian will keep copies of the submitted requests and a log of the requests, which will include the final disposition of the request. The code custodian will determine the extent of the change or problem and will obtain approval from the proper line of management to implement the 
change. A Software Revision Record form will be completed and returned per HNF-PRO-464, Software Practices - Software Control.

2. -- Create a temporary version of LLCEDATA and LLCECALC for Windows within a system test area, and alter either or both programs as required by the requested change.

3. Once the changes have been made, validate the algorithms in the code that have been revised by comparison.

4. Prepare documentation describing the change per HNF-PRO-439, Supporting Document Requirements, and issue it for approval. Complete software document control requirements per HNF-PRO-460, Software Practices - Software Document Control.

5. Upon approval of the documentation, establish the temporary version as the official version by copying the appropriate files for LLCEDATA and/or LLCECALC to new CDs. Two CDs are stored in the WMNW records storage area, and a copy is maintained by the code custodian.

6. When a significant number of modifications and improvements have been made to the programs LLCEDATA and LLCECALC, the software will be reissued with a new version number.

\subsection{REQUIREMENTS SPECIFICATIONS}

Programs LLCEDATA and LLCECALC for Windows are written to analyze and characterize the contamination of LLCE as they are retrieved from the high level waste storage tanks. The requirements listed here are selected to provide guidelines appropriate to this environment. They define an acceptable level of performance.

1. The computed ${ }^{137} \mathrm{Cs}$ activity for LLCE will agree with hand calculation to within 1 percent when both software and hand calculations employ identical assumptions and measurement data.

2. The contamination characterization will accurately reflect the limits as established by current regulations and applicable SARPs.

The validation and verification test results reported in previous sections show that these specifications are met with the current software. It should be emphasized, however, that the methodology depends on the validity of several assumptions, some of which have not been verified. These assumptions are discussed in companion Volume II: Technical Manual. Also, there are severa! limitations to the measurement approach, which are discussed in Volume II.

\subsection{SUMMARY}

LLCEDATA and LLCECALC generate characterization information by integrating both the acquisition of current tank waste data with the output from the LLCE GEA System. LLCEDATA and LLCECALC allows for the quick, accurate, and efficient characterization of an LLCE.

Three manuals document LLCEDATA and LLCECALC for Windows. Volume $I$ is a user's manual, which is intended for quick reference. It is to be used as an aid for learning to use LLCEDATA and LLCECALC for Windows and as a guide to the program's uses. The user's manual contains a discussion of all the options available to the user for each menu found in both L.LCEDATA and 
LLCECALC. The user's manual also contains three test cases that allow the user to verify the correct installation and setup of the software.

Vötume II is a technical manual, which contains in-depth information on both programs. It gives information on the history of LLCEDATA and LLCECALC for Windows, as well as the theoretical background, calculational methodology, and quality assurance for the software program.

Volume III demonstrates the software verification and validation for both LLCEDATA and LLCECALC. The contents of the databases used by LLCEDATA are verified and referenced. Each step performed by both phases of LLCECALC has been independently validated through extensive testing with synthetic data that facilitate hand calculation of results for comparison to program results. These test cases confirm that the methodology, algorithms, and data used in LLCECALC are correct.

\subsection{REFERENCES}

10 CFR 61, "Licensing Requirements for Land Disposal of Radioactive Waste," Code of Federal Regulations, as amended.

49 CFR 173, "Shippers--General Requirements for Shipments and Packagings," Code of Federal _ Regulations, as amended.

HNF-MP-599, Project Hanford Quality Assurance Program Description, Fluor Daniel Hanford, Inc., Richland, Washington.

HNF-PRO-439, Supporting Document Requirements, Fluor Daniel Hanford, Inc., Richland, Washington.

HNF-PRO-460, Software Practices - Software Document Control, Fiuor Daniel Hanford, Inc., Richland, Washington.

HNF-PRO-464, Software Practices - Software Control, Fluor Daniel Hanford, Inc., Richland, Washington.

HNF-PRO-469, Software Practices - Change Request and Problem Report, Fluor Daniel Hanford, Inc., Richland, Washington.

WAC 173-303, "Dangerous Waste Regulations," Washington Administrative Code, as amended.

CRC, 1997, D. R. Lide, Editor, CRC Handbook of Chemistry and Physics, $78^{\text {th }}$ Edition, CRC Press, Inc., Boca Raton, Florida.

DOE, 1988, Radioactive Waste Management, DOE Order 5820.2A, U.S. Department of Energy, Washington, D.C.

DOE-CAO, 1996, Waste Acceptance Criteria for the Waste Isolation Pilot Plant, DOEMIPP-069, Rev. 5. U.S. Department of Energy, Carlsbad Area Office, Carlsbad, New Mexico.

CRC, 1997, Lide, D. R., Editor, CRC Handbook of Chemistry and Physics, $78^{\text {th }}$ Edition, CRC Press, Inc., Boca Raton, Florida.

Ellefson, M. D., 1998, Hanford Site Solid Waste Acceptance Criteria, HNF-EP-0063-5, prepared by Waste Management Federal Services of Hanford, Inc., for Fluor Daniel Hanford, Inc., Richland Washington.

EPA, 1992, Test Methods for Evaluating Solid Waste, Physical/Chemical Methods, SW-846, Rev 0., U.S. Environmental Protection Agency, Washington, D.C. 
GE, 1989, Nuclides and Isotopes, Fourteenth Edition, Chart of the Nuclides, $14^{\text {th }}$ Edition, GE Nuclear Energy, General Electric Company, San Jose, California.

Grove Engïneering, 1994, RadDecay, Radioactive Nuclide Library and Decay Software, Version 5,Sottware Description and User's Manual, Grove Engineering, Inc., Rockville, Maryland.

HNF-3169, 1998, LLCEDATA and LLCECALC for Windows, Version 1.0. Volume I: User's Manual, Rev. 0, 1998, prepared by Waste Management Federal Services, Inc., Northwest Operations for Fluor Daniel Hanford, Inc., Richland, Washington.

HNF-3169, 1998, LLCEDATA and LLCECALC for Windows, Version 1.0, Volume II: Technical Manual, Rev. 0, prepared by Waste Management Federal Services, Inc., Northwest Operations for Fluor Daniel Hanford, Inc., Richland, Washington.

Kocher, D. C., 1981, Radioactive Decay Data Tables, A Handbook of Decay Data for Application to Radiation Dosimetry and Radiological Assessments, Oak Ridge National Laboratory Technical Information Center, Oak Ridge, Tennessee.

McCormick, W.A., 1997, Safety Analysis Report for Packaging (Onsite) Long-Length Contaminated Equipment Transport System, HNF-SD-TP-SARP-013, Rev. 0, prepared by Waste Management Federal Services, Inc., Northwest Operations for Fluor Daniel Hanford, Inc., Richland, Washington.

WMNW, 1997, Quality Assurance Program Plan for Project Hanford Management Contract Work, EBU-QAPP-001, Waste Management Federal Services, Inc., Northwest Operations, Richland, Washington. 
This page intentionally left blank. 


\section{APPENDIX A}

\section{LLCEDATA AND LLCECALC CHANGE REPORT} AND PROBLEM REPORT FORM 
This page intentionally left blank. 
LLCEDATA and LLCECALC Change Report and Problem Report Form

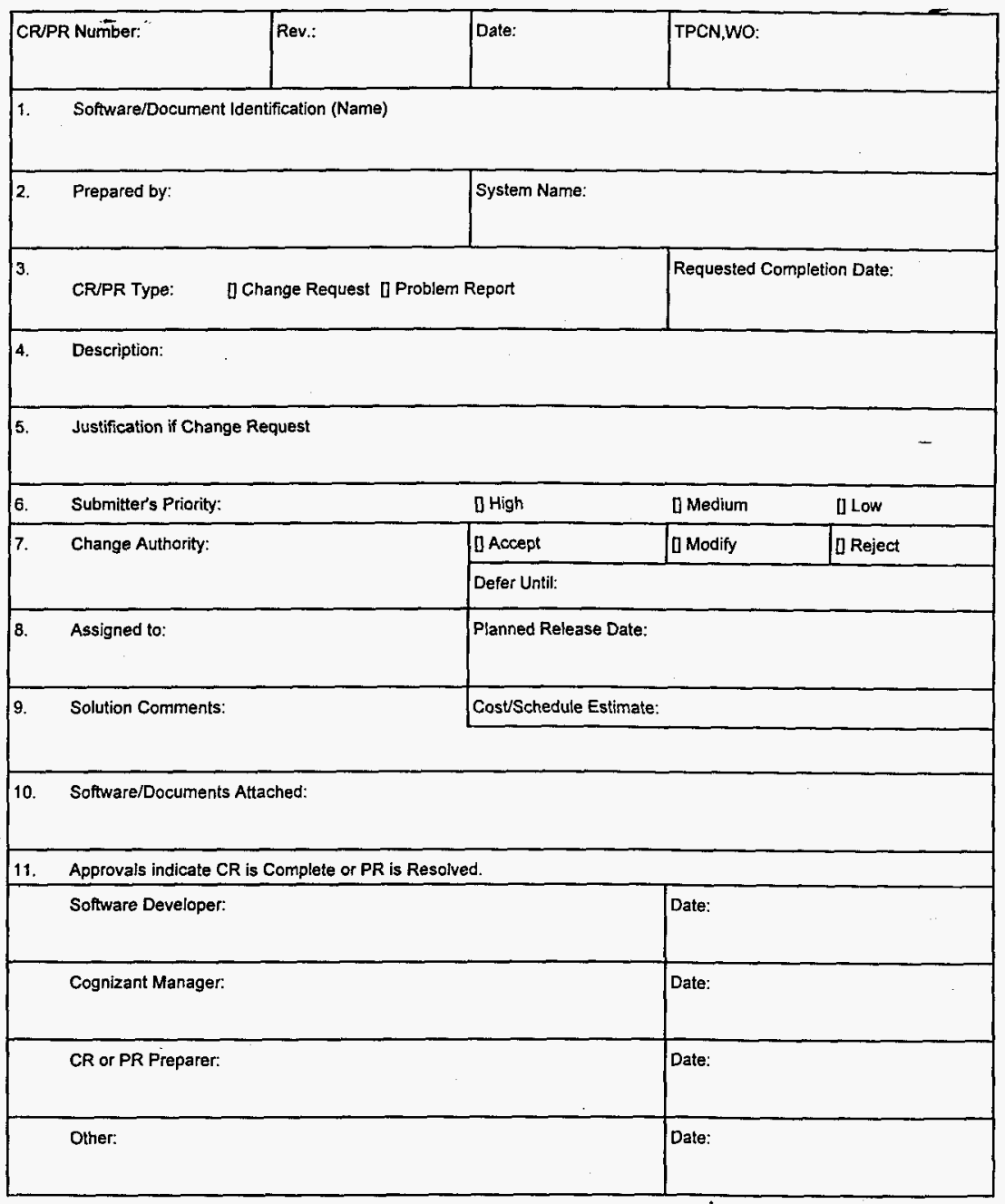


This page intentionally left blank. 


\section{APPENDIX B}

\section{VERIFICATION SPREADSHEETS FOR THE THREE CASES}


This page intentionally left blank. 
B1.0 VERIFICATION SPREADSHEET FOR CASE NO. 1

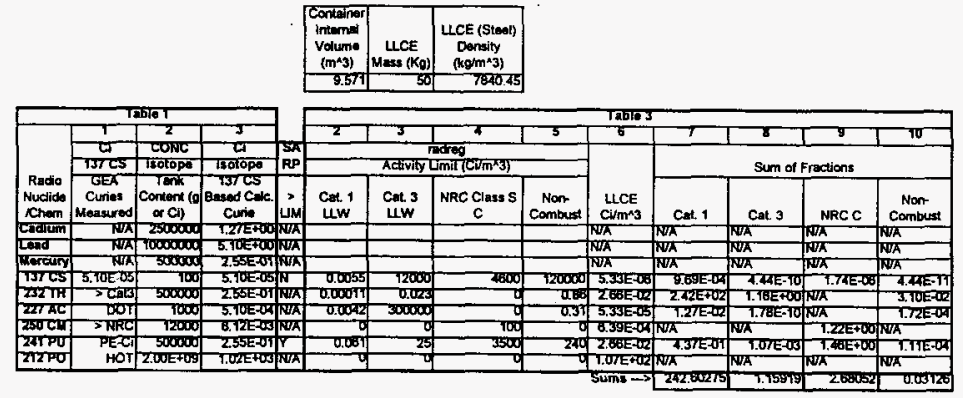

m

\begin{tabular}{|c|c|c|c|c|c|c|c|c|c|c|c|c|c|c|c|c|c|c|c|c|c|c|c|}
\hline $\begin{array}{c}\text { TRU } \\
\text { Waste }\end{array}$ & & $P E-C i$ & & & & & & & & & & \begin{tabular}{|l|}
$\mathrm{rad}$ \\
$\mathrm{rog}$
\end{tabular} & $\begin{array}{l}\text { rad } \\
\text { reg }\end{array}$ & $\begin{array}{l}\text { गहण } \\
\text { nuc }\end{array}$ & \begin{tabular}{|l}
$\mathrm{rad}$ \\
$\mathrm{reg}$
\end{tabular} & Ilce nuc & radreg & $\begin{array}{l}\text { Hico } \\
\text { nue }\end{array}$ & Hice nuc & rad reg & rad reg & $\begin{array}{c}\text { chem } \\
\text { reg }\end{array}$ & \\
\hline \begin{tabular}{|c|} 
TRO \\
Isotope \\
Conce. \\
\end{tabular} & $\begin{array}{c}\text { Curie } \\
\text { Comient }\end{array}$ & $\begin{array}{c}\text { Gram } \\
\text { Woight }\end{array}$ & PE-CI & Pu-23 & $\begin{array}{c}\text { Alpha Curie } \\
\text { Conlent }\end{array}$ & $\begin{array}{c}\text { Heat } \\
\text { Generation } \\
\text { (Watts) }\end{array}$ & $\begin{array}{l}\text { Transport } \\
\text { Category }\end{array}$ & DE.Cl & $\begin{array}{l}\text { Chem } \\
\text { Cone } \\
\text { mgng }\end{array}$ & $\begin{array}{c}\text { Code } \\
\text { Apply } \\
7\end{array}$ & $\begin{array}{c}\text { Radio } \\
\text { Chatnical } \\
0\end{array}$ & $\begin{array}{l}\text { SARP } \\
\text { Limit }\end{array}$ & NRC & $\begin{array}{l}7 \pi v 0 \\
\text { iso } \\
\text { topes }\end{array}$ & $\mid \begin{array}{l}\text { PEE-CT } \\
\text { Cort } \\
\text { Factor }\end{array}$ & Civg & $\begin{array}{c}\text { PU-z39 } \\
\text { FGE } \\
\text { Facior }\end{array}$ & $\begin{array}{l}\text { Alpha } \\
\text { Emitterer }\end{array}$ & $\begin{array}{l}\text { Heal } \\
\text { Gener. } \\
\text { (W/Ci) }\end{array}$ & $\begin{array}{c}\text { DOT A2 } \\
\text { Limit }\end{array}$ & $\begin{array}{l}\mathrm{DE}-\mathrm{Ci} \\
\text { Factor }\end{array}$ & $\begin{array}{l}\text { DCöde } \\
\text { Limit } \\
\text { (Chem) }\end{array}$ & \begin{tabular}{|c} 
Radio \\
Nuclide \\
ICherm
\end{tabular} \\
\hline NAK & NAA & N/A & N/A & W/A & NAA & NAA & N/A & NDA & 25.4961 & & 9 & & & & & & & & & & & & 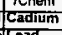 \\
\hline NAA & WNA & WIA & N/A & NWA & N/A & NRAA & N/A & WA & 101.976 & & gi & & & & & & & & & & & & Lead \\
\hline NA & WWA & NOA & WOA & NOA & Wh & $5.15 E-08$ & उ.7BE- 06 & उTGE OS & NIA & NIA & 4 & 9ार & & & & 86.5 & of & & townण & T35 & $7 \mathrm{~A}=-\mathrm{D}$ & & horcury \\
\hline N/A & NAA & NAA & NIA & NW/R & 0.2549405 & $6.07 \mathrm{E} \cdot 03$ & NhA & $9,71 E=01$ & NA & NAA & 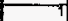 & of & & of & oे & 1.1E-OI & 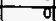 & & 0. & & 3.87 & & 2352 \\
\hline NAR & NIA & NGA & Non & WWA & Wh & 2.41EOT & 9.42E:01 & 2.0AENOS & N/K & NWA & & & & 0 & 0 & 72.34 & of & & 0.00047 & 0.00054 & th & & 2274 \\
\hline T.22E+00 & NA & NRA & Ne/K & Wa/A & 0.00011857 & & NA & NA & WWA & NWA & T & & & $T$ & & 0.159 & & & 00 & 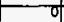 & 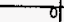 & & 2500 \\
\hline N/2 & 0.2549405 & 0.00247575 & 0.12870783 & 0.00556969 & WNA & 7.9OEDOD & 9.44E-01 & A.89E=-08 & NoA & NIA & & 0.179 & & 1 & 52 & 103 & 2.25 & & $3.1 E-05$ & 0.27 & 0.192 & & IT \\
\hline N/A & NNA & INA & NA & WhA & NA & 5,31E+ण If & $N / A$ & NIK & N/A & NA & & & & & 0 & .79E+17 & - & & 0.0521 & तो & & & $212 P$ \\
\hline
\end{tabular}

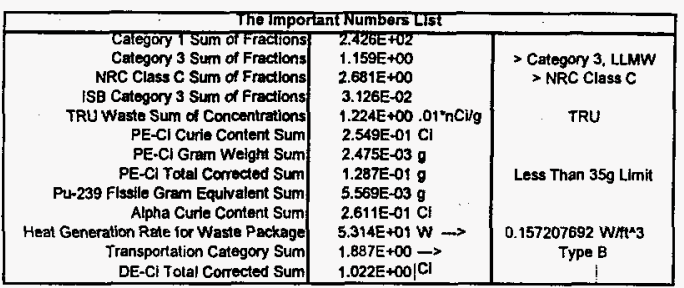

II

4 
B2.0 VERIFICATION SPREADSHEET FOR CASE NO. 2
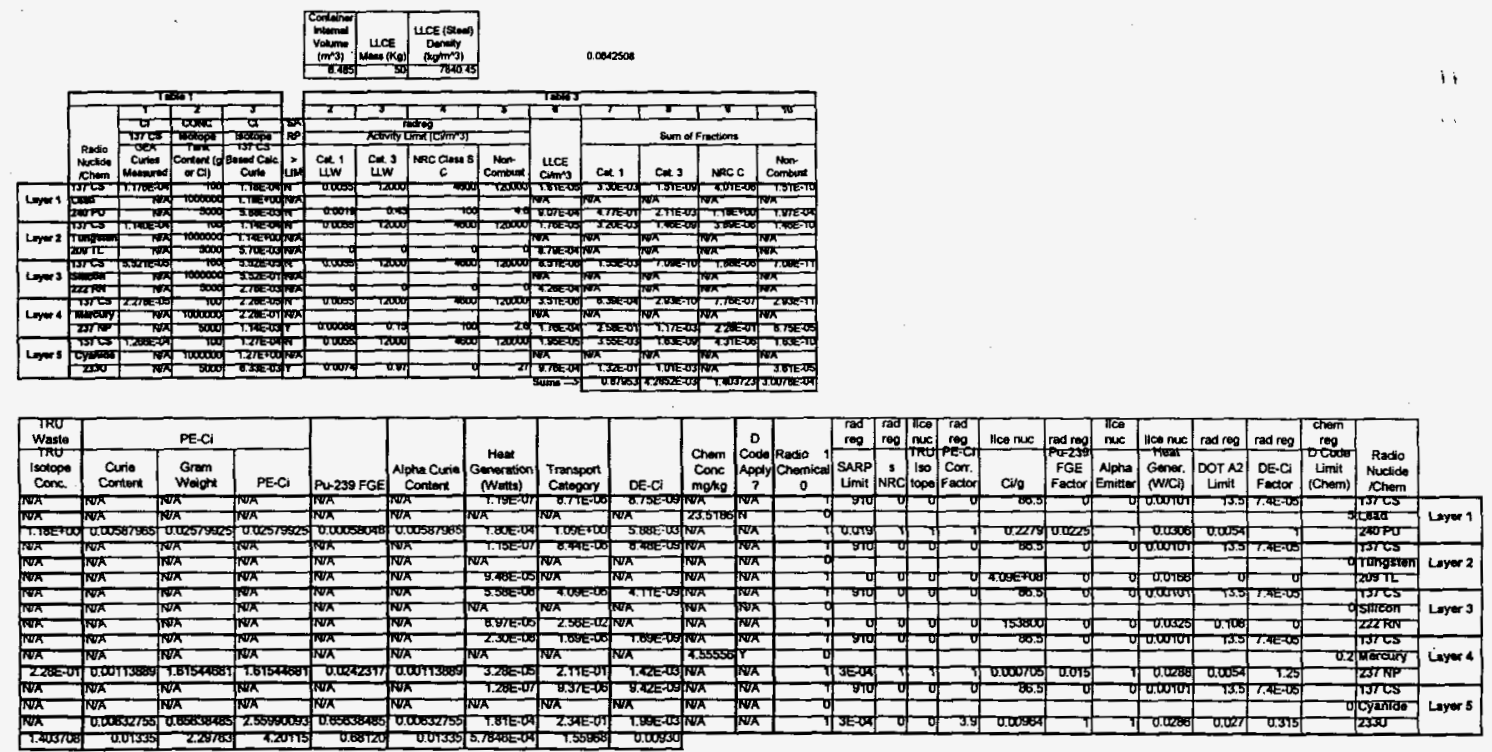

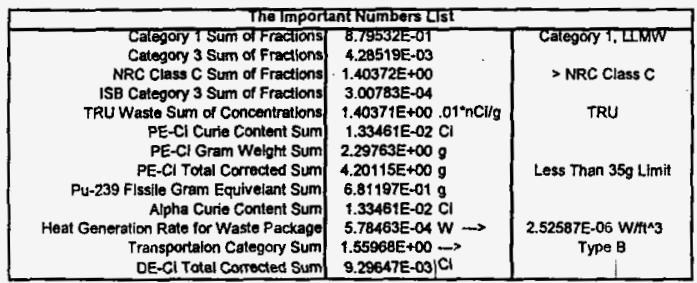




\section{B3.0 ${ }^{137}$ CS VERIFICATION SPREADSHEET FOR CASE NO. 2}

\begin{tabular}{|c|c|c|c|c|c|c|c|c|c|c|c|c|c|c|c|c|c|c|c|c|c|c|c|c|c|c|}
\hline & & $\mathrm{AV} 2$ & $\begin{array}{l}\text { Activ } \\
\text { (uCi) }\end{array}$ & ities & & & & & $\begin{array}{l}\text { ordLer } \\
\text { Change } \\
\text { orrecte } \\
\text { vities ( }\end{array}$ & $\begin{array}{l}\text { ength } \\
\text { e } \\
\text { ed } \\
\text { (uCi) }\end{array}$ & & $\begin{array}{l}\text { eometr } \\
\text { orrectio } \\
\text { actors }\end{array}$ & & $\begin{array}{r}\mathrm{Ge} \\
\mathrm{Co} \\
\text { Acitiv }\end{array}$ & $\begin{array}{l}\text { eometr } \\
\text { orrecte } \\
\text { vities ( }\end{array}$ & $\begin{array}{l}\text { try } \\
\text { ted } \\
\text { (uCi) }\end{array}$ & $\begin{array}{r}\text { Shiel } \\
\text { Corre } \\
\text { Fact }\end{array}$ & $\begin{array}{l}\text { Iding } \\
\text { ection } \\
\text { tors }\end{array}$ & Activi & $\begin{array}{l}\text { Final } \\
\text { orrecte } \\
\text { ities (u }\end{array}$ & $\begin{array}{l}e d \\
\text { (uCi) }\end{array}$ & & $\begin{array}{l}\text { tector } \\
\text { irrors } \\
\text { arcent }\end{array}$ & & $\begin{array}{c}\text { Final } \\
\text { Averaged } \\
\text { Activities } \\
\text { (uCi) }\end{array}$ & $\begin{array}{c}1 \\
\text { Layer Totals } \\
\text { (Ci) }\end{array}$ \\
\hline $\begin{array}{c}\operatorname{Rec} \\
\#\end{array}$ & $\begin{array}{l}\text { AV2 } \\
\text { End } \\
\text { Pos }\end{array}$ & $\begin{array}{c}\text { Det } \\
1\end{array}$ & $\begin{array}{c}\text { Det } \\
2\end{array}$ & $\begin{array}{c}\text { Det } \\
3\end{array}$ & $\begin{array}{l}\text { LLCE } \\
\text { Start } \\
\text { Pos }\end{array}$ & $\begin{array}{c}\text { LLCE } \\
\text { End } \\
\text { Pos }\end{array}$ & $\left|\begin{array}{l}\text { Tank } \\
\text { Layer }\end{array}\right|$ & Det & $\begin{array}{c}\text { Det } \\
2\end{array}$ & $\begin{array}{c}\text { Det } \\
3\end{array}$ & $\begin{array}{c}\text { Det } \\
1\end{array}$ & $\begin{array}{c}\text { Det } \\
2\end{array}$ & $\begin{array}{c}\text { Det } \\
3\end{array}$ & $\begin{array}{c}\text { Det } \\
1\end{array}$ & $\begin{array}{c}\text { Det } \\
2\end{array}$ & $\begin{array}{c}\text { Det } \\
3\end{array}$ & $\begin{array}{c}\text { Det } \\
2\end{array}$ & $\begin{array}{c}\text { Det } \\
3\end{array}$ & $\begin{array}{c}\text { Det } \\
1\end{array} \mid$ & $\begin{array}{c}\text { Det } \\
2\end{array}$ & $\begin{array}{c}\text { Det } \\
3\end{array}$ & $\begin{array}{c}\text { Det } \\
1\end{array}$ & \begin{tabular}{c|c} 
Det & D \\
2 &
\end{tabular} & $\begin{array}{c}\text { Det } \\
3\end{array}$ & & \\
\hline$\frac{\pi}{20}$ & 2 & 10 & 10 & 10 & NTA & NIA & N/A & NIA & N/A & N/A & NIA & N/A & N/A & N/A & N/A & NIA & |NIA & N/A & NIA & N/A & W/A & $\mathrm{N} / \mathrm{A} \mid \mathrm{N}$ & N/A & N/A & N/A & \\
\hline 30 & 3 & 10 & 100 & 70 & N/A & NIA & N/A & N/A & N/A & N/A & N/A & NIA & IN/A & |N/A & N/A & N/A & $|N / A|$ & $\mid N / A$ & N/A & N/A & N/A & N/A $\mid \mathrm{N}$ & N/A & NIA & $N / A$ & \\
\hline 40 & 4 & Tot & 10 & T0 & N/A & N/A & NIA & N/A & NIA & N/A & N/A & $|N / A|$ & NIA & N/A & N/A & N/A & NTA & N/A & NIA & N/A & N/A & N/A $\mid \mathrm{N}$ & N/A|R & N/A & N/A & \\
\hline 50 & 5 & To & रण्ण & 70 & उष्ठ & Tर्9 & 5 & 10 & 100 & To & 2 & 3 & & 20 & 30 & 70 & 7.24 & 1.19 & 20 & 37 & 12 & 2 & 2 & 2 & 23.00926 & \\
\hline 60 & की & to & 10 & 70 & 77 & 38 & 5 & 10 & 100 & 10 & 2 & 3 & t & 20 & 30 & 10 & 1.24 & 1.19 & \begin{tabular}{|l}
20 \\
\end{tabular} & 37 & 12 & 2 & 2 & 2 & 23.00926 & \\
\hline 70 & 7 & 10 & 10 & 70 & कह & 37 & 5 & 10 & 10 & 10 & 2 & 3 & $T$ & 20 & 30 & 10 & 1.24 & 1.19 & 20 & 37 & 12 & 2 & 2) & 2 & 23.00926 & \\
\hline 80 & 8 & 10 & 10 & 10 & 15 & 16 & 5 & 70 & 10 & 10 & 2 & 3 & 1 & 20 & 30 & 10 & 1.24 & 1.19 & 20 & 37 & 12 & 2 & 2) & 2 & 23.00926 & \\
\hline 90 & 9 & To & 100 & 70 & 14 & 15 & 5 & 10 & 10 & 10 & 2 & 3 & $T$ & 20 & 30 & 70 & 1.24 & 1.19 & 20 & 37 & 12 & 2 & 2) & 2 & 23.00926 & \\
\hline JEW & N/A & N/A & N/A & NJA & 13.5 & 14 & 5 & 5 & 5 & 5 & 2 & 3 & $T$ & 10 & 15 & 5 & 1.24 & $\mid 1.19$ & 10 & 19 & 6 & 2 & 2 & 2 & 11.50463 & $265509 E-04$ \\
\hline 700 & रण & 70 & To & 70 & 13 & 33.5 & 4) & t & 5 & 5 & 2 & 3 & $T$ & 10 & 15 & 5 & 1.24 & 1.19 & Tण & 19 & 6 & 2 & 2 & 2 & 77.50463 & \\
\hline 715 & NI/A & N/A & |N/A & N/A & 72.75 & 13 & & 2.5 & 2.5 & 2.5 & 2 & 3 & & 5 & 7.5 & 2.5 & 1.24 & $\mid 1.19$ & 5 & 9.3 & 3 & 2 & 2 & 2 & 5.752315 & \\
\hline NEW & $\mathrm{N} / \mathrm{A}$ & N/A & |N/A & INA & 12.5 & 12.75 & 4 & $2.5 \mid$ & 2.5 & 2.5 & 3 & t) & 2 & 7.5 & 2.5 & 5 & 1.24 & 1.19 & 7.5 & 3.1 & 6 & 2 & 2 & 2 & 5.520833 & $2.2777 / 7 \mathrm{E}-05$ \\
\hline 710 & $\pi$ & To & Tर्ण & 10 & 12 & 72.5 & 3 & 5 & 5 & 5 & 3 & $\pi$ & 2 & 15 & 5 & 70 & 1.24 & 1.79 & 15 & 6.2 & 12 & 2 & 2 & 2 & 17.04167 & \\
\hline 720 & 12 & 10 & की & 10 & $\pi$ & 12 & 3 & 10 & 10 & 10 & 3 & $\pi$ & 2 & 30 & Tof & 20 & $\mid 1.24$ & 1.19 & 30 & 12 & 24 & 2 & 2 & 2 & 22.08333 & \\
\hline 130 & 73 & 70 & 100 & 10 & Tण & गो & 3 & 10 & To & 10 & 3 & T & 2 & 30 & 10 & 20 & 1.24 & 1.19 & 30 & 12 & 24 & 2 & 2 & 2 & \begin{tabular}{|l|}
22.083333 \\
\end{tabular} & $5.520833 E-05$ \\
\hline 140 & बद्य & 100 & Tर्ण & 10 & 9 & To & 2 & 70 & 10 & 70 & 3 & 7 & 2 & 30 & 10 & 20 & $\mid 1.24$ & 1.19 & 30 & 12 & 24 & 2 & 2 & 2 & 22.08333 & \\
\hline 750 & 15 & 10 & 10 & 10 & 8 & 9 & 2 & 10 & 10 & 10 & 3 & 1 & 2 & 30 & Tof & 20 & 1.24 & $\mid 1.19$ & 30 & 12 & 24 & 2 & 2 & 2 & 22.08333 & \\
\hline 765 & N/A & NIA & |N/A & INIA & 7.5 & 8 & 2 & 5 & 5 & 5 & 3 & $\pi$ & 2 & 15 & 5 & 10 & 1.24 & 1.19 & 15 & 6.2 & 12 & 2 & 2 & 2 & 17.04167 & \\
\hline 160 & 16 & Tण & To & 10 & 7 & 7.5 & 2 & 5 & 5 & 5 & 7 & 2 & 3 & 5 & 10 & 15 & 1.24 & 1.19 & 5 & 12 & रह & 2 & 2 & 2 & 11.75926 & \\
\hline 770 & 77 & रण & To & 70 & हा & 7 & 2 & 30 & ro & गण & $\pi$ & 2 & 3 & To & 20 & 30 & $\mid 1.24$ & 1.19 & 70 & 25 & 36 & 2 & 2 & 2 & 23.51852 & \\
\hline 780 & 78 & 10 & To & 10 & 5 & 6 & 2 & 10 & 10 & 10 & 1 & 2 & 3 & 10 & 20 & 30 & 1.24 & 1.19 & 10 & 25 & 36 & 2 & 2 & 2 & 23.51852 & $1.140046 E-04$ \\
\hline 790 & 79 & 70 & Tof & 70 & 4 & 5 & $t$ & ग0 & 70 & To & t & 2 & 3 & T0 & 20 & 30 & 1.24 & 1.19 & रण & 25 & 36 & 2 & 2 & 2 & 23.51852 & \\
\hline 200 & 20 & 10 & 10 & 10 & 3 & 4 & if & To & 10 & To & 1 & 2 & 3 & 10 & 20 & 30 & 1.24 & 1.19 & रण & 25 & 36 & 2 & 2 & 2 & 23.51852 & \\
\hline 210 & 21 & 10 & 10 & 10 & 2 & 3 & 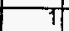 & 10 & To & 10 & if & 2 & 3 & 10 & 20 & 30 & 1.24 & 1.19 & 10 & 25 & 36 & 2 & 2 & 2 & \begin{tabular}{|l|}
23.51852 \\
\end{tabular} & \\
\hline 220 & 22 & 10 & To & 70 & 1 & 2 & 1) & Tot & 10 & To & i) & 2 & 3 & To & 20 & 30 & 1.24 & 1.19 & 10 & 25 & 36 & 2 & 2 & 2 & 23.51852 & \\
\hline 230 & 23 & 10 & 10 & 10 & o & & $\pi$ & 100 & 10 & 10 & 7 & 2 & 3 & 5 To & 20 & 30 & 1.24 & 1.19 & 10 & 25 & 36 & 2 & 2 & 2 & $23.51 \mathrm{B52}$ & T.175925E-04 \\
\hline
\end{tabular}




\section{DISTRIBUTION SHEET}

\begin{tabular}{|c|c|c|c|c|c|}
\hline \multirow{2}{*}{$\begin{array}{l}\text { To } \\
\text { Distribution }\end{array}$} & \multirow{2}{*}{\multicolumn{3}{|c|}{$\begin{array}{l}\text { From } \\
\text { Packaging Engineering }\end{array}$}} & \multicolumn{2}{|l|}{ Page 1 of 1} \\
\hline & & & & \multicolumn{2}{|c|}{ Date August 27, 1998} \\
\hline \multicolumn{4}{|l|}{ Project Title/Work Order } & \multicolumn{2}{|c|}{ EDT No. 622942} \\
\hline \multicolumn{4}{|c|}{$\begin{array}{l}\text { LLCEDATA and LLCECALC for Windows Version } 1.0 \text {, Volume III: } \\
\text { Software Verification and Validation (HNF-3169, Rev. 0) }\end{array}$} & \multicolumn{2}{|c|}{ ECN No. $\quad N / A$} \\
\hline Name & MSIN & $\begin{array}{c}\text { Text } \\
\text { With All } \\
\text { Attach. }\end{array}$ & Text Only & $\begin{array}{l}\text { Attach./ } \\
\text { Appendix } \\
\text { Only }\end{array}$ & $\begin{array}{l}\text { EDT/ECN } \\
\text { Only }\end{array}$ \\
\hline $\begin{array}{l}\text { R. R. Connolly } \\
\text { D. W. Crass (2) } \\
\text { M. D. Ellefson } \\
\text { J. G. Field } \\
\text { D. C. Hetzer } \\
\text { D. E. Legare } \\
\text { W. A. McCormick } \\
\text { J. C. McCoy } \\
\text { J. G. McFadden (2) } \\
\text { M. A. McGhan } \\
\text { D. L. Riley } \\
\text { H. L. Roach } \\
\text { T. Romano } \\
\text { R. D. Wilson } \\
\text { Document Processing Center } \\
\text { HNF-3l69 File } \\
\text { Work Control (D. Kelly) }\end{array}$ & $\begin{array}{l}\text { T4-05 } \\
\text { R3-47 } \\
\text { T3-05 } \\
\text { H1-15 } \\
\text { S6-31 } \\
\text { R3-47 } \\
\text { H1-15 } \\
H 1-15 \\
\text { H1-15 } \\
\text { H1-15 } \\
\text { H1-15 } \\
\text { H5-57 } \\
\text { H1-15 } \\
\text { H1-15 } \\
\text { A3-94 } \\
\text { H1-15 } \\
\text { H1- } 15\end{array}$ & $\begin{array}{l}x \\
x \\
x \\
x \\
x \\
x \\
x \\
x \\
x \\
x \\
x \\
x \\
x \\
x \\
x \\
x\end{array}$ & & & $X$ \\
\hline Central Files & $B 1-C$ & $\lambda$ & & & \\
\hline
\end{tabular}

